\title{
LA CELIA DE LOPE DE VEGA
}

Cuando después de cuatro años de relaciones estrechamente íntimas con Elena Osorio, se ve Lope de Vega despedido, recibe una herida profunda en su corazón y en su amor propio. Muchos atractivos tendría el apuesto mozo, pero es lo cierto que era la segunda mujer que, cuando la creía conquistada, le abandona por otro. De la primera no hizo gran duelo; se trataba de una afición venial, que según él "como no fué amor de peso, púdolo el viento llevar" y además encontró pronta y crecida compensación en Elena. Ahora el caso variaba mucho: había llegado a los brazos de la Osorio, si no antes de apuntarle el bozo, lo bastante tierno para que esa mujer modelara su sensibilidad erótica a su antojo.

En una comedia escrita hacia I 588 reconoce el mal influjo que había recibido cuando hace decir a Belardo, quien se precia de no guardar fe amorosa :

Aquesto y más aprendí.

de aquella que yo adoré

¡buen discípulo quedé!

¡bien puedo matar por mí! ${ }^{1}$

Elena, de más edad que él, ducha en las artes de la seducción, le hizo recorrer todos los grados de la pasión amorosa: dulce cariño, amor desorbitado, raptos de locura, celos dilacerantes, reconciliación, odio incontenible, persecución y, por último, abandono. Furioso Lope ante la traición de la amada se dedica a escribir versos de maldecir en los que llega a describir intimidades bochornosas y explica:

Yo no pensaba en mi vida

de lo que digo alabarme;

pero, cuando le desprecian,

bien puede un hombre alabarse ${ }^{2}$.

${ }^{1}$ Urzón y Valentino (Acad, vol. XIII, pág. 500 a). Atribuyo a esta comedia la fecha más baja que señalan Morley y Bruerton (1588-1595) en The chronology of Lope de Vega's comedias (obra capital a que con frecuencia tendré que referirme, y que para abreviar lo haré con la sigla MB). Acaso fuese la obra dramática algo anterior a la ruptura final con Elena, porque el deslizar furtivamente el nombre de Belisa no es forzoso que ya estuviese casado con ella.

2 Romance inédito que se encuentra en el ms. 2700 de la Bibl. Nac, fol. $16 \mathrm{r}$. 
El despecho va en aumento y, ya desbocado, escribe las desvergonzadas sátiras ${ }^{3}$ contra Elena y sus parientes, las cuales pronto corrieron de mano en mano. Demandado por los Velázquez, el padre y el tío de la Osorio, fué Lope condenado a destierro de dos años del reino de Castilla y a ocho de alejamiento a cinco leguas de la corte (febrero de 1588$)^{4}$.

Esta condena por infamación acaso nos parezca hoy excesiva; pero la justicia en aquella época se nos presenta, a la vez que severa, equitativa, y por escándalo sabemos que en aquellos años sufrieron destierro y prisión personas de alta representación social ${ }^{5}$. Díganlo, por citar los más significativos, el que había de ser gran duque de Osuna, entonces mozalbete jaranero, desterrado de Sevilla, y el $5^{\circ}$ Duque de Alba, castigado por una veleidad amorosa ${ }^{6}$. ¿Por qué se había de tratar con más benignidad a un joven poeta sin "comodidad" (acomodo, empleo), ni oficio, ni trato ninguno de que sustentarse?". Más extraño es que tuviesen tanto poder unos representantes para que se atendiese a reparar su deshonra; pero Cervantes aconseja por boca de Sancho "no tomarse con farsantes... que como son gentes alegres y de placer, todos les amparan, ayudan y estiman" ". Sin duda sería de decisivo apoyo la categoría del rival de Lope en el servicio de Elena, D. Francisco Perrenot, sobrino del eminente Cardenal Granvela .

${ }^{3}$ Cervantes escribía en la $2^{*}$ parte del Quijote: "Es propio y natural de los poetas desdeñados y no admitidos de sus damas, o fingidas en efeto de aquellos a quien ellos eligieron por señoras de sus pensamientos, vengarse con sátiras y libelos; venganza por cierto indigna de pechos generosos". Muchos años habían pasado desde la venganza de Lope para que el tiro fuese contra él; pero tantos le asestó Cervantes que acaso esto lo escribió recordando lo pasado, y tampoco sabemos cuándo lo escribiría.

4 Pérez Pastor y Tomillas publicaron el proceso. Luego Joaquín de Entrambasaguas encontró los libelos para desdicha de su autor, porque además del lenguaje soez, hay que convenir en que los versos son muy malos. Lope nos tiene acostumbrados a tratar en sus comedias los asuntos más viles con dignidad poética; los rufianes y cortesanas de sus comedias se mueven a ras del suelo, sin encenagarse; pero en estas sátiras habla la cólera sin el freno del arte.

${ }_{5}^{5}$ Precisamente el año 1587 trató Felipe II de reformar las costumbres de los caballeros de su corte que vivían muy ociosos, y fué causa de que desterrasen al conde de Paredes y a los marqueses de Peñafiel y Cogolludo. (Véase Cabrera de Córdoba, Felipe II, vol. III, pág. 206).

- Pocos años antes el $4^{\circ}$ duque de Alba don Fadrique de Toledo fué encarcelado y perseguido con ensañamiento por el monarca con motivo de una supuesta promesa hecha a una dama de la corte, sin que se atendiese ni a sus propios servicios en las guerras, ni a las súplicas de su padre el gran duque don Fernando.

7 Declaración de un testigo. Proceso, pág. 59.

8. Quijote, II, cap. xn.

- Creo que no haya que insistir ya en que don Francisco y no don Tomás fué quien suplantó a Lope en el amor de la Osorio. Además de una lectura más exacta de las notas manuscritas en el ejemplar del Romancero de 1604 que se encuentra en la Bibl. Nac. (R. 2171) coincide con el dato de ser de más edad que Lope, y también sabemos que por su conducta, harto libre, ocasionó disgustos al Cardenal y fué motivo de que le desheredase. 
El año 1588 fué en la vida de Lope de abrumadora intensidad en acontecimientos. Condenado en el mes de febrero, estaba obligado a salir inmediatamente de la corte desde la cárcel, y a los quince días fuera del reino. Cuando andaba despechado de Elena, para despicarse, amarteló a doña Isabel de Urbina. Era ésta una doncellita, a la sazón de I 7 años, criada en un hogar honesto, de familia acomodada (la antítesis de la desenvuelta Osorio), y se dejó seducir por la voz de sirena del poeta. Su oscura existencia la rastreamos en los versos de Lope, quien al convertir toda su vida en literatura, las personas que le rodean llegan a ser propiamente entes dramáticos a los que presta voz, y él, en medio de todos, representa el primer papel. No queremos decir que se pueda extraer de esa obra literaria unas biografías históricas, que es difícil discernir el límite entre la realidad y la fantasía, pero obtendremos una representación de lo que el autor quiso que se supiese, y ello no es poco. Sobre todo conocemos sus reacciones ante los sucesos de su vida manifestadas en sus obras.

Cuando más se apartaba Elena, más apremiantes eran los versos que dirigía Lope a doña Isabel para que se rindiese. Trata de persuadirla de que no tiene por qué temer que él se acuerde más de Elena.

Si Filis te ha dado celos

el tiempo te desengaña, que como ella quiere a otro, puede por otra dejarla ${ }^{10}$.

Cierto que era expresión no muy amorosa, mas pudiera ser convincente.

Era natural que la familia Urbina no aprobara aquellos amores, muy especialmente siendo por entonces Lope "la fábula de la corte"; pero el alocado galán en el punto que se ve obligado a apartarse de Madrid, con un golpe de audacia, rapta o hace raptar a doña Isabel. Se querella el padre, pero el asunto no tiene más componenda que el subsiguiente matrimonio y Lope en ro de mayo se casa por poder con aquella víctima propiciatoria, que había de pagar su impremeditada decisión con una vida corta de duración, pero abundante en sacrificios.

En un romance muy conocido, escrito en Valencia, acaso en el mismo año I 588, conmemora Lope el suceso: cuando él, Belardo, paseaba por la corte muy engalanado

$$
\begin{aligned}
& \text { desde su balcón } \\
& \text { me vió una doncella } \\
& \text { con el pecho blanco } \\
& \text { y la ceja negra; }
\end{aligned}
$$

${ }^{10}$ El romance empieza "Amada pastora mía". Se publicó en la Primera Flor de Romances con licencia de 1588 y se encuentra también en el Cancionero Clasense, ms. de 1589 . Existen de él unas cuantas versiones y el mismo Lope copió unos versos en su comedia La Arcadia (Acad, vol. V, pág. 735 a). 


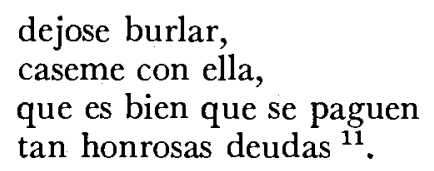

No citaremos aquí todos los romances que Lope dedicó a doña Isabel por reservarlos para el romancero del Fénix, y sólo aludiremos a los que ilustren el período que estudiamos. La pareja Belardo-Belisa animó el romancero nuevo pastoril, y el morisco con muy variados nombres, más difíciles de identificar.

Apenas habían acabado de comer los picos de la rosca de la boda, cuando el recién casado abandona a la esposa para alistarse en la gran Armada contra Inglaterra, y el 20 de mayo embarca en Lisboa. Mucho se ha discutido sobre el móvil que le impulsó a esta decisión ${ }^{12}$ y hay quien supone que no llegó a navegar porque en su obra, tan llena de impresiones personales, no hay rastro del desastre de semejante expedición, que de haber arrostrado las desdichas que en ella ocurrieron, no le faltaron ocasiones de haberlas aludido para honra suya. Él nos ha dicho que se embarcó en Lisboa, y aunque no tengamos comprobantes documentales, no hay motivo para no creerle.

Lope habla en algunas obras de la malhadada expedición, pero sólo de los preparativos, acaso con el deliberado intento de no recordar el descalabro. Hay en la Dragontea (año 1598) una alusión, que como hecha de pasada y sin comentario, nos prueba ser verdad que se embarcó en la Armada. Hablando de que según decían Francisco Draque tenía un familiar en un anillo, añade:

Soldados de la nave en que yo iba a Inglaterra, aquí me lo han contado, que en ocho años de prisión esquiva que en la corte de Londres han pasado oyeron estas cosas que refiero ${ }^{13}$.

${ }^{11}$ El romance que empieza "Hortelano era Belardo" se difundió rápidamente, pues el Cancionero Clasense de $15^{89}$ (publicado por A. Restori, pág. I 74) incluyó ya una versión. Tenemos otra, atribuida certeramente a Lope en el cartapacio de Pedro de Penagos de h. 1593 (ms. de la Bibl, de Palacio). Está también incluido en la $6^{a}$ parte del Romancero General de $\mathrm{I} 600$. Su autor lo recuerda años después en dos comedias: Las paces de las rayas de h. I6I (Acad, vol. VIII, pág. $390 \mathrm{~b}$ ) y Al pasar el arroyo de I6I5 (AcadN, vol. XI, págs. 268 a y 367 b). Asimismo se canta en Más vale salto de mata, comedia mal atribuida a Lope (AcadN, vol. VII, pág. $390 \mathrm{~b}$ ). Salas Barbadillo cita dos versos en La ingeniosa Elena de I6I2. Todavía en i 63o Polo de Medina (Obras completas, pág. 9o) copia los cuatro primeros modificando el tercero con otro también muy conocido de Lope "porque un consonante obliga".

12 El motivo de alistarse pudo ser para eludir el castigo en que había incurrido de ir a remar en galeras por haber entrado en la corte. Acaso se quedó en la Coruña con las naves que allí arribaron obligadas por la primera tempestad que las combatió a poco de hacerse a la mar.

${ }^{13} O$. S., vol. III, pág. 341. Con esta sigla designaré la Colección de las obras 
Al partir Lope de Toledo para Lisboa escribe unas liras despidiéndose amargamente de la patria. A la abandonada esposa dedica la estrofa final, algo alambicada si la comparamos con otros muchos versos emocionados que dedicó a otras ausencias.

Dulce, señora mía, ya de nuestro llorado apartamiento llegó el amargo día;

las velas y esperanzas doy al viento; de vos me aparto y quedo, si con dejar el alma partir puedo ${ }^{\mathbf{I} 4}$.

Esta canción, que comienza "Sola esta vez quisiera", se encuentra impresa por primera vez en la Tercera parte de Flores de Romances ${ }^{\mathrm{I5}}$, donde consta de sólo cuatro liras y termina con la despedida a la "señora". Al pasar al Romancero General de i6oo se intercaló una estrofa más alusiva a los enemigos envidiosos. Algunos años después la incluyó su autor en la novela Arcadia apropiada a Anfriso (el $5^{\circ}$ duque de Alba) y hace constar que fué compuesta por un pastor del Tajo (Lope) y puesta en música por otro del Betis (Palomares) ${ }^{\text {I'́ }}$. Esta nueva versión añade 12 estrofas dedicadas a insistir en las quejas contra los envidiosos perseguidores y la ingratitud de la patria, sentimientos muy repetidos por el Fénix en diversas obras. La canción dilatada hasta 17 liras perdió la emocionada intimidad de la poesía inicial y la unidad y brevedad apropiadas para que le pusiese tonos Palomares ${ }^{17}$. Todavía en 162 I al

sueltas de Lope de Vega editada por Antonio de Sancha, (1776-79). Para otras alusiones véase J. Mrlué y Grménez, Estudios de literatura española, pág. 103.

${ }^{14}$ La forma estrófica no es la de las liras de Garcilaso y Fr. Luis de León, sino la de seis versos ( $\mathrm{a}$ B a B c C) que fué la predilecta de Lope para las canciones compuestas en la época de que tratamos.

${ }^{15}$ La Biblioteca Nacional posee un ejemplar de esta Tercera Flor (R. 9799)

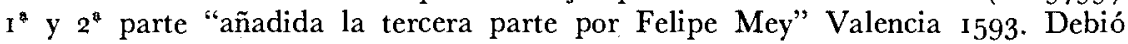
existir alguna edición anterior puesto que conocemos una "Cuarta y quinta parte" de 1592.

${ }_{16} O S$, vol. VI, pág. 87

17 La estrofa de despedida con la antítesis "de vos me aparto y quedo" inspiró a Lope uno de sus más famosos sonetos: "Ir y quedarse y con quedar partirse" $(O S$, vol. IV, pág. 219), publicado en las Rimas de ı602. Otra versión de un ms. de la Biblioteca Nacional citada por Gallardo (Ensayo, vol. I, col. I05I) fué publicada en $R H i$, XVIII, pág. 534. La expresión del enamorado que al ausentarse siente los cuerpos alejados mientras permanecen unidas las almas es común a muchas obras poéticas. Faría y Sousa, con su escasa sensibilidad de poeta, se burla de ello: "Esto de ir y quedar en sus ausencias los amantes, partir y no partir y semejantes fullerías..." (Rimas, pág. $276 \mathrm{~b}$ ). Lope atinó en este soneto a dar forma adecuada al concepto y de ahí su resonancia en otras literaturas. El mismo Faría cita en otro lugar de sus Rimas (pág. 244 b) el primer verso del soneto sin nombrar al autor. El anónimo portugués autor de Fénix Renascida dice en una "Epístola a un amigo": "Ir y quedar y con quedar partirse dise o Fénix de Hespanha que era ausencia". En el Parnaso, publicado en Portugal en I88o con mo- 
publicar La Filomena se deleita el poeta en copiar la primera estrofa de la canción y recuerda el llanto que hicieron los pastores cuando partió desterrado por una venganza amorosa ${ }^{18}$.

Cuando estaba a punto de embarcar en Lisboa dedica un romance a la esposa abandonada inspirado en el tema clásico de las quejas de Dido, sin que haya por su parte muestra de pesar ${ }^{19}$.

Al volver Lope de la expedición naval y tener que salir desterrado del reino de Castilla, se refugia en Valencia. Las letras florecían en la ciudad levantina protegidas por los gremios que gustaban de dar oportunidad en sus fiestas a los poetas para ejercitar su arte. Había además allí una tradición: Timoneda editor y poeta pocos años antes había remozado los viejos romances y había ensayado el teatro popular: los dos órganos en que Lope empezaba a hacerse famoso. Los autores dramáticos contaban con locales fijos para poner en escena sus obras, existían actores y un público aficionado. Rey de Artieda y Virués habían ensayado sin gran éxito la tragedia y con ella alternaban las representaciones de carácter popular. Lope llegó a punto de fundir esas dos corrientes en la nueva comedia, ejerciendo una influencia decisiva sobre la nueva generación de poetas en la que figuraban Gaspar Aguilar, Guillén de Castro, el jovenzuelo Carlos Boyl y el canónigo Tárrega, de más edad, quien ya había compuesto algunas obras dramáticas.

De las prensas de Valencia salían en abundancia pliegos sueltos, entregas y libritos que contenían romances nuevos que veían la luz sin nombre de autor y cuya identificación da hoy tanto que hacer a los eruditos, quienes van descubriendo la amplia acogida que los editores prestaban a las fáciles composiciones del poeta forastero.

Si desde el punto de vista literario se encontró Lope en un medio grato, su posición económica distaba de ser halagüeña. Vivir de la pluma es siempre difícil y más entonces: si no se tenía una base de sustentación fija, eclesiástica o castrense, había que recurrir a entrar al servicio de algún grande, y con nada de esto contaba Lope en Valencia. Sabemos

tivo del centenario de Camoens se incluyó como de este autor el soneto español, error que corrigió Carolina Michaëlis de Vasconcellos en $R H i$, XXII, pág. 530. El insigne poeta italiano Marino, tan admirado por Lope, tradujo y publicó entre sus poesías nuestro soneto traducido, callando el original y el nombre del autor. Por último, Lope mismo lo aludió en su comedia El ausente en el lugar de h. r6o4 (AcadN, vol. XI, pág. 429 a). "Qué propio es en amor, como lo cantan, / ir y quedar y con quedar, partirse". Precede en la comedia un diálogo en que se discretea con las mismas palabras: "Tanto partir y quedar / fué siempre de amor rodeos". Y como prueba de expansión duradera valga esta cita de Polo de Medina: "Cuando de Murcia partí / ¡Oh, qué bien aquí viniera / lo de quedarse y partirse, / versos de Lope de Vega!"

$18 O S$, vol. VI, pág. 80.

19 No damos aquí importancia alguna al encuentro que tuvo Lope con una mujerzuela en Lisboa la noche antes de embarcar, y que después de muchos años refirió al Duque de Sesa, su señor, que tanto gustaba de esa clase de confidencias del secretario. Ni siquiera merece el nombre de aventura amorosa. 
que la compañía de Quirós representó allí algunas comedias del Fénix, que de diversos puntos acudían los representantes a pedirle sus obras y que tenía un contrato con Gaspar de Porres en que se comprometía a entregarle cada dos meses una comedia. Pero que esto no bastaba lo prueba que, en cuanto pasaron los dos años de destierro del reino, se trasladó a Toledo en busca de acomodo.

En una epístola dirigida a Claudio Conde años más tarde reconoce la abnegada solicitud con que le acompañó doña Isabel en los penosos días que padeció a la vuelta de la Armada:

$\mathrm{Y}$ quien pudiera imaginar que hallara volviendo de la guerra dulce esposa, dulce por amorosa y por trabajos cara ${ }^{20}$.

Sin embargo la canción que dedicó a Belisa en las playas de Valencia es más de tono burlesco que de acendrado cariño ${ }^{21}$. La esposa, embarazada y presa de desesperación, como en el romance de Lisboa, agravada ahora por los celos, está a punto de arrojarse al mar. Sale un delfín bramando, ella se asusta y abandona su propósito de suicidio ${ }^{22}$.

Lope a poco de llegar a Toledo entró al servicio de don Francisco de Ribera, futuro $2^{\circ}$ Marqués de Malpica. Con él debió de ir a Madrid pues en la corte firmó su comedia El principe inocente el 2 de junio de $\mathbf{I}_{590^{23}}$. Desempeñaría corto tiempo su empleo, pues don Francisco andaba de pretendiente en palacio y Lope no podía prolongar mucho tiempo su estancia allí, que todavía pesaba sobre él pena de destierro.

Después el $5^{\circ}$ duque de Alba, don Antonio de Toledo, le recibió como gentilhombre, y acompañando a éste su señor pasó Lope cinco años entre Toledo Novés, la Abadía y por fin en Alba. Cantó los amores del duque en multitud de obras, cuyo estudio formará capítulo aparte. Ahora sólo nos interesa averiguar cómo manifestaba sus propios sentimientos amorosos.

Ya hemos visto cuán poco calor ponía después de casado en los versos dedicados a la esposa que, fuerza es decirlo, el matrimonio le inspiraba verdadero hastío y, según su costumbre, no lo oculta: "Si es

$20 \mathrm{OS}$, vol. IX, pág. 357.

21 El romance que empieza "De pechos sobre una torre" ha sido estudiado y reconstruido con notable esmero y sagacidad por Arturo Zavala, comparando los diversos textos conocidos con una imitación a lo divino (RevBN, VI, 1945).

22 De esta cobardía mujeril también se mofa cuando en el romance "Contemplando estaba Filis" (Romancero General de 1600 , fol. 21 c, y con variantes en el ms. de la Bibl. Nacional. R3915, fol. 127, fechado en 1620) supone a Filis enojada y fiera, a punto de atravesarse con un cuchillo; mas sólo por ver la sangre de un pinchazo de aguja, se turba y arroja el arma.

23 Véase a A. G. DE AMEzúa, Una colección manuscrita y desconocida de comedias de Lope de Vega. Deseamos ver pronto la anunciada edición de esa comedia desconocida. 
propia, es aborrecida / la más hermosa mujer", nos dice en una comedia fechada en Alba ${ }^{24}$.

En La hermosura de Angélica nos explica el motivo de semejante desvío:

Que vela ajeno amor y el propio duerme...

y nadie estima lo que tiene y goza:

es la propia mujer prenda segura,

y amor con miedo de perderse dura ${ }^{25}$.

Esto escribía en vida de doña Isabel; pero ese desprecio del vínculo legal asoma, con breves años de interregno, a lo largo de su vida o de su obra, que es lo mismo. En la Dorotea nos hace observar que "no quiso la lengua castellana que de casado a cansado hubiese más de una letra de diferencia". Y en la misma obra nos dice que "en el casamiento, la posesión acaba con el amor o con la vida" ${ }^{26}$.

Todavía en otra ocasión advierte que:

Dura amor con el temor

de perder lo que se ama;

que cuando dueño se llama,

pierde las fuerzas amor ${ }^{27}$.

Únicamente el advenimiento de los hijos justifica y alegra la vida de los desposados; "que supuesto que es lazo el matrimonio / mientras faltan los hijos, falta el nudo" 28 .

En un soneto de La mocedad de Roldán, después de enumerar los beneficios que pueden alcanzarse con el matrimonio, deduce que todo es trato incierto, gusto sin efecto;

Mas cuando con los hijos se confirma,

es entre los casados cierto el trato,

la paz segura y el amor perfecto ${ }^{2.9}$

24 Laura perseguida, AcadN, vol. VII, pág. I I3.

25 La Angélica, OS, vol. II, pág. 97.

${ }^{26}$ La Dorotea, I, vi, y IV, III.

2خ Lo fingido verdadero, Acad, vol. IV, pág. 69 b. No incluyo entre los versos de amor "Sirvió Jacob los siete largos años" (OS, vol. IV, pág. I9 I), imitación, sólo en el comienzo, del precioso soneto de Camoens, porque juzgo que en él Lope habla en nombre de otro, como ocurre con frecuencia. Se trata de alguien no muy satisfecho de su matrimonio, pero que a diferencia de Jacob que podrá gozar su Raquel, porque en "efecto viva", él "espera a su Raquel en la otra vida". No se ajusta esa situación a ningún momento conocido de la vida de Lope. De ningún modo es, como se ha supuesto, que desease la muerte de doña Isabel, que no le estorbaba para amar a otra mujer. En Los pastores de Belén volvió a tratar el caso de Jacob y Raquel y termina con la deducción: "que la engañosa posesión destruye / lo que entretiene el bien en esperanza".

28 Los Porceles de Murcia, Acad, vol. XI, pág. 567 b.

29 Acad., vol. XIII, pág. 2 I I a. Supongo esta comedia, como otras carolin- 
Lope, entre sus nobles apasionamientos, tenía un profundo sentido de la paternidad con que supo esmaltar muchas composiciones aún muy anteriores a los emocionados versos que dedicó a Carlos Félix.

Algunos pasajes de la Angélica nos dan la sensación de estar inspirados por doña Isabel ${ }^{30}$; pero luego en los muchos retoques que sufrió el poema, hasta que se publicó en 1598 , se trasladan en honor de la bella de ojos azules. La dulce esposa fué incapaz de saciar la desbordada apetencia vital de los $3^{0}$ años de aquel en tantos aspectos "Monstruo de Naturaleza". Sólo cuando contempla a la desdichada joven que se extinguía, y después que estuvo muerta, sintió él un profundo y sincero arrepentimiento que tradujo en cariñosos versos ( $O S$, vol. IV, pág. $\left.{ }^{2} 3^{8}\right)$.

Más abundante es la producción de Lope dedicada a recordar a Elena durante el destierro. Se sentía hondamente agraviado y quiere convencernos de que "yo juré que en un hora, habiendo agravio / no sólo sé olvidar, sino aborrezco" ${ }^{31}$; pero tenemos muy averiguado que a veces le dominó el odio, pero nunca alcanzó el olvido, y eso a pesar de encontrarse subyugado por el convencimiento de que los celos averiguados enfrían el amor y se convierten en agravios: "Amé con celos, mas con desengaños / no pienso que es amor, sino locura" 32 .

Náufrago del amor tormentoso y cuando parecía curado de sus antiguas locuras, acude al templo del Desengaño: "Ya vengo con el voto y la cadena / Desengaño santísimo, a tu casa".

Este soneto fué incluido en el Galán escarmentado ${ }^{33}$ y luego, como otros muchos, pasó a las Rimas con ligeras variaciones para invocar el nombre de Lucinda.

A este mismo período en que le obsesiona el desengaño debe adscribirse la famosa canción "La verde primavera / de mis floridos años", una de las mejor logradas, en la que expresa cómo se entregó al loco amor, hasta que el desengaño le libertó de su cautiverio:

Con voz libre y exenta

al desengaño santo

consagro altares y alabanzas canto.

Se publicó esta canción en la Sétima parte del Romancero General de 1600 con el descuido frecuente en esa edición: hasta omite un verso

gias, anterior a 1599 que es el término a quo que le señalan Morley y Bruerton basados en que hay alusión a Lucinda, pero ya veremos que es base inconsistente.

${ }^{30}$ Por ejemplo, cuando después de alejarse de Elena por completo (canto XIX) dice: "Y fuime a aquella / que fué para salvar mi nave, estrella".

31 Algunos romances ocasionales he citado en Mediterráneo, II, 1944, y en NRFH, III, 1949, págs. $37^{8-38} 5$.

${ }^{32}$ Soneto que intercaló en la comedia Lo fingido verdadero.

${ }^{33} \operatorname{AcadN}$, vol. I, pág. 123 b. 
entero. En versión más correcta se encuentra al final de la novela $A r$ cadia $^{34}$ y hay otra en un manuscrito de Nápoles de fines del siglo xvi (el Cancionero de Matías Duque de Estrada), que publicó Eugenio Mele $^{\mathbf{3 5}}$. Lope tenía muy presentes en la memoria los versos de esta canción; con los dos primeros ligeramente variados termina un soneto de la comedia Arcadia ${ }^{36}$. Con igual modificación para convertir los dos heptasílabos en un endecasílabo los encontramos en la Jerusalé $n^{37}$. Se hallan asimismo en un soneto de las Rimas sacras de $1614^{38}$, y todavía esos dos versos los menciona en ${ }_{1} 62$ I en la dedicatoria de la edición de El dómine Lucas $^{39}$.

Sigue llamando en su ayuda al desengaño en apasionados sonetos y en tono menor en algún romance como el que lleva el belicoso estribillo:

¡Al arma, al arma, guerra, desengaños

que me lleva el amor mis tiernos años $!^{40}$

Pero, según su temperamento, Lope se arrepiente pronto y exclama:

... ¡Oh, quien no pensara en desengaños

o se desengañase de tenellos!

y debatiéndose con más rigor:

¡Oh, siempre aborrecido desengaño

amado al procurarte, odioso al verte,

que en lugar de sanar, abres la herida!

Pluguiera a Dios durases, dulce engaño;

que si ha de dar un desengaño muerte, mejor es un engaño que da vida.

Es en vano cuanto ha hecho por olvidar aquel tan violento amor pasado, que sigue atormentándole, y lo peor es que no sabe callarlo. Tal acongojada situación le inspira el soneto de una tersura magnífica, exento de artificio:

Pasé la mar, cuando creyó mi engaño que en él mi antiguo fuego se templara; mudé mi natural, porque mudara

34 OS, vol. VI, pág. 459.

${ }^{35}$ BHi, IIl, rgor, pág. 355 .

${ }^{36}$ "Hijos sois de mi amor, no sois extraños, / celos, porque tenéis en fuego etemo / la verde primavera de mis años". (Acad, vol. V, pág. $726 \mathrm{a}$ ).

${ }^{37} O S$, vol. XIV, pág. 415. Aquí se usan para expresar un pensamiento contrario en boca de Lucinda: "Pasé libre de amor y de sus daños / la verde primavera de mis años".

${ }^{38}$ OS, vol. XIII, pág. 184 . "Aqú́ cuelgo la lira que desamo / con que canté la verde primavera / de mis floridos años".

${ }^{39} \operatorname{AcadN}$, vol. XII, pág. 6o. Como verso suelto aparece en un relato de $E i$ genovés liberal (AcadN, vol. VI, pág. 135 b).

40 Cancionero musical de C. De la Sablonara, ed. 1918, pág. 303. 
naturaleza el uso, y curso el daño.

En otro cielo, en otro reino extraño mis trabajos se vieron en mi cara, hallando, aunque otra edad pasara, incierto el bien y cierto el desengaño.

El mismo amor me abrasa y atormenta y de razón y libertad me priva. ¿Por qué os quejáis del alma que lo cuenta?

Que no escriba, decís; ¿o que no viva? Haced vos con mi amor que yo no sienta, que yo haré con mi pluma que no escriba. ${ }^{4 \mathrm{I}}$

Para él, vivir, amar, cantar eran realidades inseparables.

A tono con este soneto de no poder desasirse del recuerdo, encontramos otro romance muy difundido que, como el del estribillo anteriormente mencionado, cifra en Io años el tiempo que ha estado sujeto al amor de Filis:

¡Oh memorias invencibles que en la mía podéis tanto que estáis agora más nuevas que al principio de diez años!

Entre los ojos traigo que tengo de morir enamorado ${ }^{42}$.

Se ha querido ver en esta reiteración de recuerdos de Elena un mero tópico, pero lo cierto es que aquella musa sigue inspirándole sonetos, romances y canciones, lo mismo en las playas de Valencia que a orillas del Turia, del Tajo o del Tormes. Quizá la llama se reavivase cuando en 1590 Lope estuvo en Madrid ${ }^{43}$, o cuando ese mismo años coincidió en Toledo con la compañía del representante Jerónimo Velázquez.

He citado dos romances que dilatan a 10 años el recuerdo de Filis, y con ellos pueden agruparse otras composiciones de la misma fecha que nos llevan hacia el año $1593^{44}$.

Los versos son a veces de reconciliación, como la canción en ágiles liras en que se da por contento de sufrir destierros y agravios siendo la causa de ellos tan bella. No faltaban como contraste los versos de

$41 O S$, vol. IV, págs. 270, 200, 239 y 230.

42 La difusión de este romance que comienza "iAh gustos de amor traidores!" nos lo prueban las versiones conservadas. Desde luego se halla en el Romancero General de 1600, $7^{*}$ parte (fol. 22 I b.). Otra versión se conserva en un ms. de fines del siglo xvi de la Bibl. de Palacio ( $2 \mathrm{H}_{4}$ fol. $107 \mathrm{v}^{\circ}$ ). En un Romancerillo de Barcelona publicado en $R H i$, XXIX, pág. 158, puede verse otra copia. En La Dorotea (OS, vol. VII, pág. I55) hay cita de los cuatro primeros versos.

43 Nos revela esa estancia la suscrición de la comedia ya citada de El Príncipe inocente.

44 El diez podemos tomarlo como número redondo y la fecha $\mathrm{I} 593$ como aproximada. 
maldecir para en ocasiones terminar en arrepentimiento; ese movimiento oscilatorio de toda la vida de Lope:

Lo escrito y mal hablado

no es mucho, ingrata Filis, que te asombre,

si, como condenado,

blasfemo algunas veces de tu nombre,

llorando el alma mía

diez años tristes sin alegre día ${ }^{45}$.

En otro romance (también de los ıo años), se disculpa graciosamente con una de esas comparaciones tomadas de la vida cotidiana de que tanto jugo sabía sacar nuestro poeta:

Digo mal del bien que adoro no más de porque me falta...

Quien alguna cosa pierde, cuando no espera cobralla, con la boca la desprecia y quiérela con el alma ${ }^{46}$.

A pesar de la insistencia del recuerdo, falta en estas últimas composiciones el ímpetu de la pasión, sea de amor o de odio, a que nos tenía acostumbrados en otro tiempo; son ahora como un eco que se aleja, unas llamaradas de un fuego que se extingue.

En El dómine Lucas, comedia fechada en Alba en I 593, lanza Lope la execración: "perjura, infame rama del linaje Osorio" y como para nada intervienen en la obra los Osorios, hemos de convenir que es un desahogo del poeta, que lanza a modo de una losa bajo la que quiere sepultar todo el recuerdo ${ }^{47}$. Pero no nos dejemos engañar, que con destellos de aquella pasión seguirá Lope iluminando sus obras posteriores. Dejando a un lado comedias llenas de alusiones y poesías menores, citaremos algunas obras entre las que el poeta creía de mayor importancia. En La Angélica, Lucindo, un pobre pescador, cuenta sus amores siguiendo estrechamente el patrón de los de Lope y Elena ${ }^{48}$. En El Peregrino, obra terminada en i6o3, tenemos análogo relato contado por un ermitaño, con todo deta-

45 De esta canción tenemos dos versiones con pequeñas variantes: una procede de un ms. del siglo xvi que se conserva en la Bibl. Nac. y publicada por Gallardo (Ensayo I, col. 1201). La otra pertenece al Laberinto amoroso (ed. 1618) y fué transcrita por K. Volmöller ( $R F$, VI, $189 \mathrm{I})$. Véase J. F. Montesinos en $R F E$, XII, pág. 285 .

46 Romancero General de 1600 , fol. 44 a. Ya en El verdadero amante (pág. $663 \mathrm{~b}$ ), había dicho: "El sentimiento por el bien que se pierde sólo dura hasta que es cierto su perdimiento".

${ }^{47}$ AcadN, vol XII, pág. $7^{8}$ a. G. 7. Northup hizo notar esta alusión en $M L N$, XXIV, Igog, pág. 62.

48 OS, vol. II, pág. 320. 
lle y las circunstancias que concurrían en Elena ${ }^{49}$. En La Filomena, obra tardía ( I622), valiéndose de alegorias en otras cuestiones de su vida, vuelve a contarnos la realidad de su trato con Elena. Y sobre todo ten emos La Dorotea, que según dice, es historia, la cual escrita en su juventud, al publicarla remozada, ya septuagenario, siente con fruición el regusto de aquel juvenil amor.

Póstuma de mis musas Dorotea y por dicha de mí la más querida ${ }^{50}$.

¿La musa o la mujer?

Lope en las obras de la vejez en que hace resumen de su vida llega a olvidar no sólo a sus esposas, sino hasta la idolatría que profesó a Micaela, y salta de la pasión de Elena a la de doña Marta.

El eclipse total que sufrió el ya desvaído amor nos lo explica un soneto lleno de efusión, de íntima confidencia ${ }^{51}$.

Marcio, yo amé y arrepentíme amando de ver mal empleado el amor mío; quise olvidar, y del olvido el río huyóme, como a Tántalo, en llegando.

Remedios vanos sin cesar probando, venció mi amor, creció mi desvario; dos veces por aquí pasó el estío, y el sol nunca mis lágrimas secando.

Marcio, ausentéme, y en ausencia un día miráronme unos ojos, y mirélos; no sé si fué su estrella, o fué la mía.

Azules son, sin duda son dos cielos, que han hecho lo que un cielo no podía: vida me da su luz, su color celos ${ }^{52}$.

Es un soneto de admirable construcción en que los tercetos nos llevan a participar de aquel súbito arrobamiento. En un solo verso condensa el flechazo: "miráronme unos ojos y mirélos" y en pocas palabras nos da la característica de aquellos ojos: luz y color.

Además, podemos interpretar ese poemita desde el punto de vista autobiográfico, con lo cual gana en concreción. Desde luego está escrito en Alba, donde lleva dos años ( I 59 I-92), sin conseguir olvidar su desvariado amor, hasta que en una ausencia, de las que hacía acompañando

${ }^{49}$ Algo mayor que el galán, "gallarda, de ingenio claro y atrevido, a quien con el buen natural había hecho diestra la experiencia. No me costó la posesión de su casa muchos pasos ni hacienda..." (OS, vol. V, pág. 123).

so $O S$, vol. IX, pág. 367.

$51 O S$, vol. IV, pág. 214.

52 Al mismo amigo había dirigido un soneto en que le habla del desengaño que le invadía (OS, vol. IV, pág. 269). 
como gentilhombre a su señor, queda cautivo de aquellos ojos azules que logran "lo que un cielo no podía". En esta última frase creemos ver una alusión a doña Isabel cuyas amables prendas reconocía, pero que no colmaban sus deseos.

En el horizonte erótico de Lope había aparecido una nueva estrella que llevará el nombre poético de Celia. Como vemos en el soneto copiado, brota la pasión como una llama pujante que amenaza un incendio de amor. Ahora, como en tantas otras ocasiones, el romancero nos va a descubrir el comienzo de esta nueva idolatría. El romance es la forma más adecuada para recoger las confidencias cotidianas, admite desde el tono más familiar al más sublime, no exige atuendo alguno, y además, merced a su connatural carácter de anonimía, corre sin que se haga notorio el autor. Así los versos del principio de estos amores fueron un enigma indescifrable.

Son latines para el vulgo que quién es Celia no sabe

nos dice el autor en uno de los romances (que pasamos a examinar), procurando una cautela en él desusada.

En cuatro romances, que pueden formar serie, incluidos en un cartapacio manuscrito de I $59^{\circ}$ a I6oo, conservado en la Biblioteca de $\mathrm{Pa}$ lacio $^{53}$ encontramos cómo empezó el trato de Lope con Celia. No los copio íntegros porque, como se verá por las muestras, son de escaso valor literario, bastante artificiosos, abundan en antítesis, juegos de palabras y tópicos que se encuentran en la novela Arcadia y otras obras de Lope de su primera época.

En el primer romance, nos dice el poeta que se halla ante Celia en calidad de tercero y archivo de sus secretos; pero la bella le ha robado el alma y su situación le pone en grave aprieto: si se declara, será condenado a perpetuo destierro de su vista, que es la única gloria que remedia sus males; por otra parte

$$
\begin{aligned}
& \text { y si como es fuerza callo } \\
& \text { y en la sentencia consiento } \\
& \text { los estribos de paciencia } \\
& \text { me faltan y el sufrimiento, } \\
& \text { pues miro que de las prendas } \\
& \text { que me tienen a mí preso } \\
& \text { lleva con libertad otro } \\
& \text { la victoria y el trofeo. } \\
& \text { Sufra mi corazón, pues su consuelo } \\
& \text { está en sufrir agravios de su cielo }{ }^{54} \text {. }
\end{aligned}
$$

s3 Ms. 2, H. L.

54 El estribillo era muy usado en los romances de esta época. 
Está perdido entre celos y desamor y no halla modo de conseguir su deseo. En el segundo romance, Belardo (ya aquí aparece el nombre) se ha decidido a poner entre las manos de Celia un papel en que declara su pasión. El castigo de su osadía es inmediato,

pues desde aquel propio día, que fué para él noche ciega, no sólo le niega el habla, pero su vista le niega... Sólo viendo malograda su sin segunda firmeza, de la que es causa de todo dice, formando mil quejas: ¡Ay Celia ingrata! bella cuanto fiera ¿por qué permites que sin verte muera? ¿En qué te ofenden mis ojos, esclavos de tu belleza, que en sólo mirar los tuyos se regocijan y alegran?...

En el tercer romance habla Celia. E1 responder aunque sea con una negativa, es la primera brecha que se abre en el muro de defensa de una mujer solicitada. No hay, le dice, por qué la llame ingrata; ella sabe que la ama.

Pero advierte por quien eres, si hay advertencia en amante, que mi gusto no dormía cuando tú le despertaste...

Fué temprana mi afición y la tuya llegó tarde, que al primero en tiempo di de mi libertad la llave...

Todo ello no hace más que aumentar en Belardo el deseo y los celos. En el cuarto romance muestra su desesperación, que él entregó su alma en rehenes y sólo recibe sinrazones que le tachan de infame y traidor.

En resumen, en estos romances se trata de un tercero que aspira a ser primero en el amor de una mujer comprometida de antemano con otro. Es un tema repetido mil veces en la literatura y en la historia, mas a pesar de que sea una situación trivial, no olvidemos el detalle.

Muchos versos escribió Lope para vencer el rigor de Celia, que según parece se hizo mucho desear. No podía decir como de Elena "que fué muy blanda en el primer concierto". No faltaron tampoco ocasiones en que tuvo que acallar celos de ella y también de la desdichada esposa.

Los romances, que son hojas sueltas del libro de memorias, tienen el grave inconveniente de no estar fechados. Para poder fijar en el tiem- 
po la aparición de Celia necesitamos un hito cierto que nos oriente en nuestra investigación. Felizmente en esta ocasión vamos a hallar la guía donde menos podía esperarse: en una comedia hagiográfica, la de $S a n$ Segundo fechada por el mismo Lope en Alba el año I $594^{55}$. En esta comedia encontramos una escena en que Hermógenes, que enseña las artes mágicas a Fileto (recuérdese la afición de Lope a estos estudios), al verlo incrédulo le dice: ¿Qué quieres ver que esté ausente?; a lo que el neófito expone:

\section{Amo a Celia eternamente porque es en extremo hermosa}

e inmediatamente se le aparece en un espejo ${ }^{56}$.

Celia no interviene para nada en la obra y esa escena está desligada del resto de la comedia. Este romper el tapiz de fondo de la acción para que entre los hilos asome un momento su amada es muy del gusto de Lope, y en este caso demuestra que la obsesión por Celia era ya incontenible para él en 1594 .

En $L a$ pastoral de Jacinto hay también un momento en que el pastor Belardo, que pasa por mágico, se aparta a un lado para cantar de Celia.

$$
\begin{aligned}
& \text { Dadme, Musas, ahora } \\
& \text { vuestro divino aliento, porque quiero } \\
& \text { de Celia, a quien adora } \\
& \text { mi alma, y de quien ser esclavo espero, } \\
& \text { pintar en verso rudo } \\
& \text { la perfección que tiene el cielo mudo }{ }^{57} \text {. }
\end{aligned}
$$

Son versos de esperanza, no de un amor logrado. Celia no aparece tampoco en la acción y la escena es meramente un esparcimiento del poeta. Esta comedia no tiene fecha, pero debió de escribirse en Alba, pues el protagonista está ligado a la casa ducal, vive en la sierra de Béjar y a su padre le paga tributo todo el valle de Corneja (los duques de Alba

55 Debió de escribirla Lope para la inauguración en la catedral de Ávila de la capilla de San Segundo que había sido costeada por el obispo don Jerónimo Manrique. Fué este prelado el protector del poeta en sus estudios juveniles, y Lope, que entre sus virtudes tuvo la de la gratitud, le recuerda siempre con cariño, hasta en su testamento.

${ }_{56}$ La fuente literaria de esta escena se halla en la égloga Pharmaceutria, imitación de la del mismo nombre de Virgilio que publicó Lope en la segunda parte de las Rimas ( 1604 ). En ella se esfuerza Lope por demostrar cuán mendaces son esas artes adivinatorias. No sabemos cuándo fué escrita, pero la escena de la aparición de la amada no sólo la aprovechó en la citada comedia de I594 sino también en la novela Arcadia que escribía por esos años. Esta vez hace protagonista del suceso a Anfriso (el $5^{\circ}$ duque de Alba).

57 AcadN, vol. V, pág. $65^{\circ}$ a. Tres romances de la $6^{*}$ parte del Romancero Gneral de r6oo guardan relación con esta comedia: el pastor Jacinto recibe nriden de partir a Extremadura con su ganado y se queja de la obligada ausencia. 
eran señores de Valdecorneja). En la dedicatoria que antepuso a la comedia el autor cuando la publicó en $1623^{58}$ dice que la escribió en su juventud y que está inspirada en lo que "por ventura pasaba en los suntuosos palacios de los príncipes" ${ }^{39}$.

En el Cancionero de Matías Duque de Estrada, manuscrito del siglo xvn de la Biblioteca Nacional de Nápoles, se hallan dos romances atribuidos a Lope de Vega, inspirados por Celia ${ }^{60}$. Son versos incolores, unos de descripción de un jardín con abundante enumeración de plantas tan del estilo de Lope; otros están dedicados a la satisfacción de haber averiguado la falsedad de una sospecha.

De algún romance de Celia se acordó Lope en época tardía para incluirlo en sus comedias, tal el que empieza "Recordad (o Despertad) hermosa Celia" en que se queja de su crueldad. En El saber puede da$\tilde{n} a r^{61}$ (de h. I620) cantan unos músicos.

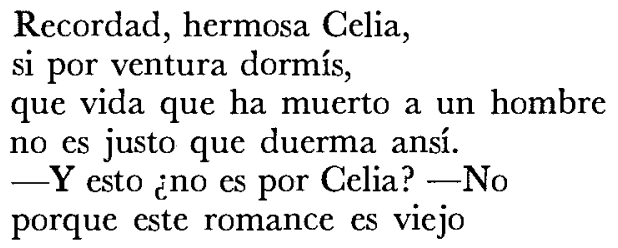

responde el criado a la pregunta del galán celoso. Y siguen cantando los músicos cuatro versos más.

Este romance lo parafraseó a lo divino el mismo Lope en el auto $L a$ locura por la honra ${ }^{62}$ y tuvo enorme difusión como lo prueban las múltiples versiones que han llegado a nosotros; siendo de advertir que apenas hay variantes de unas a otras; sin duda debió ir desde muy pronto acompañado de música como en la comedia citada. Se halla en la Docena parte de romances ( 1602 , fol. I07) y, en los Romanceros Generales de I604 (fol. 435 a) y de I 605 , y por último en el Jardín de amadores

58 Décima octava parte de sus comedias.

59 Pudiera muy bien ser el protagonista don Diego de Toledo, el bastardo del Condestable de Navarra, al que el $5^{\circ}$ duque de Alba daba lugar de hermano, y que muríó trágicamente a los 20 años en los toros con que la Villa de Alba festejó la absolución del proceso, absolución que permitió al duque don Antonio, al cabo de tres años de destierro, unirse definitivamente con su desposada doña Mencía de Mendoza. Si se trata efectivamente de don Diego, esta comedia nos suministraría el dato del lugar de su nacimiento, cuando dice que fué la sierra de Béjar donde nace Tormellas. Es éste un río del que nadie se acuerda sino Lope, tan conocedor de aquellas tierras y amigo de consignar detalles vivos. El nombre permaneció en su memoria, pues entre las muchas notas que puso a su Jerusalén en que predominan las de erudición clásica, halla cabida la cita de ese insignificante río (OS, vol. XIV, pág. $\left.5^{24}\right)$.

60 Fueron publicados por E. Mele en el BHi, 1901, págs. 349 y $35^{2}$.

61 AcadN, vol. XIII, pág. 608 a.

62 Acad, vol. II, pág. 640 b. 
de 1679 (fol. I7). La versión más vieja, aunque no sea tampoco la primitiva, nos la ofrece el manuscrito de fines del siglo xvi 2-H-4 que se conserva en la Biblioteca de Palacio.

Alguna composición del Romancero General de 1600 en que se nombra a Celia podemos atribuirla a Lope, por ejemplo la que empieza: "Frescas aguas transparentes" (fol. $332 \mathrm{~d}$ ) con largas recapitulaciones, y el grácil romancillo hexasílabo que le sigue: "Celia de los ojos" en que juega con el nombre de la amada ${ }^{63}$. Otro romance de la Trecena parte del Romancero de $\mathrm{I} 6 \mathrm{o}_{4}$ inspirado también por Celia contiene el concepto muy repetido en los versos del comienzo de esos amores de colocarse el poeta en un plan de humildad, merecedor del castigo cual otro Ícaro por haberse atrevido a alcanzar su divina belleza ${ }^{64}$.

A los primeros años de estos amores corresponde la canción más arrebatadora, impregnada de cálido sensualismo, dirigida a Celia, escrita en Alba en el otoño de I 595, cuando Lope no veía llegar el momento tan anhelado de dar por terminado su destierro. "Sentado en una peña", a orillas del Tormes siente soledades de Celia que está junto al Manzanares. No quiere pensar que le pueda allí coger el noviembre sin ver los ojos celestiales de su amada.

La nieve de tus pechos es el invierno que sufrir deseo.

Viva el rico Albano (el duque Antonio) en aquellas ásperas montañas, celebrando el nacimiento de su esperado hijo (nació en 5 de agosto de I 595) mientras él ansia verse en Madrid entre los brazos de Celia:

A vos mi patria cara el cuerpo que me distes llevar quiero, y a aquella fénix rara, por cuyo amor tan justamente muero, el alma de esta vida al vivo fuego de su altar rendida.

Ya en esta canción el amor ha llegado a un grado excelso ${ }^{65}$.

Entre los sonetos de las Rimas publicadas en 1602 pudiéramos señalar varios, sin temor a equivocarnos, como inspirados por Celia, aunque no figure nombre alguno o conste el de Lucinda, el preferido en los momentos de publicarse. Muy especialmente los dedicados a cantar el

${ }^{63}$ El mismo juego se encuentra en la epístola de Belardo a Amarilis (OS, vol. I, pág. 476 ).

${ }^{84}$ En el Romancero de 1605 hay bastantes romances dedicados a una Celia que no son de Lope sino de un poeta de las orillas del Pisuerga y estudiante en Salamanca; acaso el mismo Miguel de Madrigal, el compilador de este romancero.

${ }^{65}$ Está escrita en liras y se conserva en las Flores de poetas ilustres de Pedro de Espinosa (ed. I896, pág. 154). 
desdén de la amada pueden corresponder al período largo en que ella ofreció resistencia a entregarse. Pero dejando aparte esos versos de fechación hipotética atengámonos a los que nos consta que pertenecen a la época que venimos estudiando.

En el soneto "No tiene tanta miel Ática hermosa", encarece la intensidad de su amor cuyos suspiros exceden en cantidad a cuanto hay de innumerable en el mundo ${ }^{66}$. Su autor lo incluyó en $E l$ grao de Valencia, comedia de fecha indecisa, pero desde luego escrita durante el destierro. Al reescribirlo para las Rimas y dedicarlo a Lucinda varió ligeramente los tercetos.

Otra versión del mismo soneto nos ofrece un manuscrito de la Bibl. de Palacio en un cartapacio de J. López de Sande, fechado en ${ }_{595}$ Guando los versos se copiaban en uno de esos cuadernos de aficionados hay que suponer que habían necesitado algún tiempo para hacerse famosos. De todos modos esta composición cae de lleno en los años en que Lope cantaba a Celia. Hay en las Rimas dos espléndidos sonetos enderezados a Lucinda y que como procedentes de la Comedia de los Comendadores merecen detenido estudio. Cada uno de ellos está puesto en boca de los protagonistas, don Jorge y don Fernando, en el momento en que triunfa la voluptuosidad amorosa. Apasionadamente se dirige don Fernando a doña Aña:

Deseando estar dentro de vos propia, señora, por saber si soy querido, miré ese rostro, que del cielo ha sido, con estrellas y sol, retrato y copia. Y siendo cosa a mi humildad impropia, vime de luz y resplandor vestido con vuestros ojos, cual Faetón rendido cuando abrasa los campos de Etiopia, Pues viéndome en el cielo y paraíso, y cargado de sol, dije: Teneos, deseos locos, que me habéis burlado. Vos quitasteis los ojos de improviso, y cayendo conmigo mis deseos, fué mayor el castigo que el pecado; pero tan obstinado que otro Luzbel he sido en no ver luz ni estar arrepentido ${ }^{67}$.

Al pasarlo a las Rimas, introdujo algunas variaciones, dejando menos terso el pensamiento, y cambió la rima de los tercetos, pasando del tipo CDE-CDE del soneto dramático al de las Rimas CDC-DGD.

66 Es una imitación del italiano M. Marullo (J. Millé, $R H i$, LXVIII).

67 Uno de los pocos sonetos a que puso coda Lope, rasgo de su época temprana. 
Esto podría apoyar la teoría de $\mathrm{O}$. Jörder ${ }^{68}$, según la cual el primero de esos tipos fué el preferido por Lope en su métrica temprana. Suprimió asimismo la coda.

El tema de elevarse audazmente para conquistar un objetivo superior a su humildad es correlativo al de los romances que hemos citado del comienzo del enamoramiento de Celia en los que la osadía del amante es castigada con que ella se aparte de su vista.

El otro soneto que don Jorge, locamente apasionado, dirige a la esposa adúltera ofrece aun mayor interés.

Ya no quiero más bien que sólo amaros ni más vida, señora, que ofreceros la que me dáis cuando merezco veros, ni más gusto que veros y agradaros.

Para vivir me está bien desearos, para ser venturoso conoceros, sólo le pido a Dios para entenderos ingenio que ocupar en alabaros.

La pluma y lengua respondiendo a coros, quieren al cielo espléndido subiros donde están los espíritus más puros.

Que entre vuestras riquezas y tesoros papel y lengua, versos y suspiros de olvido y muerte vivirán seguros.

También este soneto, al incluir el nombre de Lucinda con el que pasa a las Rimas, fué notablemente variado y ganó en intensidad emotiva.

Ha de observarse el virtuosismo de la rima: en los $\mathrm{I}_{4}$ versos sólo cambia la última vocal acentuada; combina las cinco vocales -aros-eros para los cuartetos, -iros- -oros- -uros- para los tercetos. Según Otto Jörder debe colocarse este soneto de los Comendadores entre los que llama de efectos acústicos, uno de los recursos poéticos inferiores de que hacía alarde Lope en su primer estilo ${ }^{69}$. La combinación de rima de los tercetos corresponde a la misma época temprana.

En cuanto al sentimiento que inspira a este soneto es el de un vehemente deseo no saciado, sino que ha de contentarse con ver, admirar y alabar en sus versos a la amada sin obtener por el momento correspondencia. Son versos codiciosos de amor, no de plena posesión. Al final de este soneto, como en múltiples ocasiones, Lope manifiesta la

68 Otro Jörner, Das Formen des Sonnets bei Lope de Vega, Halle, r936. Trata de establecer cierta cronología en las obras del Fénix mediante una clasificación que hace de los sonetos según la rima. Los señores Morley y Bruerton no conceden importancia a este criterio; sin embargo son datos que, cuando vienen a corroborar otros, tienen su valor.

69 El recurso no fué tan frecuente en los sonetos como supone Jörder y difícilmente se hallará otro en que alcance a los 14 versos. En cambio todavía se encuentra en octavas de época tardía. 
esperanza, muy firme en él, de que sus versos, por una u otra causa, serán inmortales. Profecía cumplida.

E. Lafuente halló una copia autógrafa de este soneto que se ha conservado adherida al reverso de un relieve en escayola de asunto religioso ${ }^{70}$. Está dedicado a doña Antonia Trillo y sólo se distingue de la versión de las Rimas en que sustituye el nombre de Lucinda, sin preocuparse del hiato que resultaba al decir: "Ni más vida, Antonia, que ofreceros", ni buscó un nombre poético para la enamorada. Si no supiésemos que era un autógrafo, firmado por el autor, creeríamos que se trataba de un error de copia. El soneto estaba ya compuesto en su forma definitiva y lo traspasó al modo de "los poetas que tienen versos a dos luces $^{71}$ como los cantores villancicos, que con poco que los muden sirven a muchas fiestas"7?.

Sabíamos, por noticia del diligente investigador Pérez Pastor, que en 1596 se siguió a Lope de Vega un proceso de amancebamiento con doña Antonia Trillo. Debió de ser una aventura pasajera; acaso una encerrona preparada por la misma viudita, dueña de la casa de trucos de la calle de las Huertas, en la que se haría intervenir a los esbirros. Escenas de teatro y anécdotas históricas nos dan a conocer hechos análogos. Agradezcamos de todos modos a doña Antonia el que tan religiosamente conservase el muy preciado autógrafo.

Tenemos por lo tanto tres versiones del mismo soneto: la dedicada a Antonia Trillo, que puede fecharse en i 596, la que lleva el nombre de Lucinda que ya estaba compuesta en esa fecha, aunque no publicada hasta I602, y la que apareció en Los Comendadores, inferior en la forma y por lo tanto más vieja. Interésanos conocer la fecha de la comedia.

Cuando Menéndez Pelayo en igoo la incluyó en la monumental edición de la Academia Española del teatro de Lope de Vega, demostró que la obra estaba inspirada en un largo romance del Jurado de Córdoba Juan Rufo. La filiación de la comedia es patente: los mismos personajes con idénticos nombres y las mismas peripecias en la acción. Lope, con su maravilloso arte dramático, transformó el pesado romance ( I 240 versos) del cordobés en uno de los dramas de su primera época más llenos de vida, y de escenas más bellamente desarrolladas. Aprovechó también como elemento tradicional el Cantar de los Comendadores que en forma de zéjel, impreso en pliego suelto, recordaba el fin trágico de aquellos caballeros que había despertado el interés de los poetas desde los mismos años en que había ocurrido $(1484)^{\mathbf{7 3}}$. Una

70 Véase el sugestivo estudio, acompañado de interesantes ilustraciones grá-

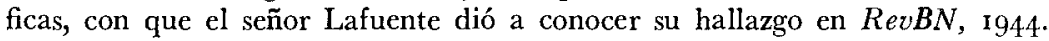

71 Comparación tomada de los candiles con dos mechas que hacen a dos luces. Tirso de Molina (BAAEE, V, pág. 205) usa "que hacéis el llanto a dos luces / como candil de mesón".

72 La Dorotea (OS, vol. VII, pág. 354).

73 Antón de Montoro escribió a raíz del suceso una composición de 17 enre- 
vez descubierta la fuente, los eruditos que han tratado de esta comedia la han fechado como posterior a I 596 , año de la publicación del romance de Juan Rufo, que vió la luz a modo de añadidura del libro de las Seiscientas Apotegmas del mismo desbaratado Jurado de Córdoba. Ha de tenerse en cuenta que Menéndez Pelayo no aventuró tal fecha para la comedia.

No tuvo Lope que esperar a esa edición para leer el romance, pues antes se publicaría en pliego suelto o en esos cuadernillos que en tanta abundancia salían de las imprentas en la última década del siglo xvi. Cuando el romance apareció en la octava parte de las Flores en i 596 , de donde pasó al Romancero General de ${ }^{1} 600^{74}$, había recorrido lo bastante para que of reciese una forma más abreviada, libre de muchas citas clásicas, reflexiones morales y otros elementos eruditos con que le había exornado el autor de la Austriada. No puede suponerse, como creía Menéndez Pelayo, que la versión del Romancero pertenezca a un refundidor que mejoró el romance de Juan Rufo; cotejadas ambas versiones, no cabe duda que se trata de un mismo romance. Ramírez de Areliano $^{75}$ es de parecer que el largo romance pertenece a la primera juventud del Jurado de Córdoba (vivió de I 547 a 1620 ) y también indica, aunque sin decirnos de donde toma la noticia, que los versos se publicaron en tirada especial anterior a 1596 . La división en cinco romances con sendos encabezamientos y remates y hasta el título destacado en forma desusada en el Romancero General, dan indicio de que se trata de la reproducción de un pliego suelto.

González de Amezúa en el importante estudio que acompaña a su edición de Las Apotegmas ${ }^{76}$ publica una relación en prosa que forma parte de una miscelánea ${ }^{77}$ de fines del siglo xvi y comienzos del xvir que él supone es la fuente inmediata de la comedia de Lope. Con esa relación coincide en los detalles en que se aparta del romance: los amantes culpables son dos parejas, más la de los criados (los antihéroes de las comedias); el esclavo denunciador está enemistado con la criada por-

vesadas octavas dedicada "A la muerte de los hermanos comendadores" (Cancionero de Montoro, ed. Igoo, pág. 38). Muy poco después Fernando de la Torre en su Cancionero (ed. Dresde, I907, pág. 132) toma esa historia para componer parte de un juego de naipes por coplas, que dedicó a la Condesa de Castañeda. La trágica muerte tuvo también su eco en un cantarcillo popular que se difundió mucho y se glosó en distintas formas. Se conserva en un pliego suelto y en el Cancionero llamado Flor de enamorados de Juan de Linares (1573). (En la ed. de ${ }_{15} 62$ no está). Como elemento tradicional Lope aprovechó dos versos del viejo y muy difundido romance de La Adúltera: "Rabia le mate los perros y aguilica el su falcón."

74 Fol. $263 \mathrm{v}^{\circ}$.

75 Juan Rufo...estudio biográfico y crítico. Madrid I9I2, pág. 100.

76 Las seiscientas apotegmas de Juan Rufo, ed. Bibliófilos Españoles, 1923.

77 Ms. de la Academia de la Historia, letra del siglo xvn. "Libro de cosas notables que han sucedido en la ciudad de Córdoba" recientemente publicado en Bibliófilos Españoles. La relación se halla en la pág. 273. 
que ella le abandona para entregarse al lacayo de los Comendadores. No falta ni el aderezar la cena y las camas para la orgía amorosa. Desde luego hay motivo para admirarse del "respeto", como dice Juliát8, que el Fénix guardaba a sus fuentes. Pero al llegar al punto culminante, aquel en que el rey después de oír la disculpa del Veinticuatro a su censura por haberse desprendido del anillo, don regio, le dice a modo de sentencia: "Si a tu mujer se lo diste, que tu mujer te lo dé" nos encontramos en la relación con estos dos octosílabos que son los que escribió el autor dramático y que llegan a ser tema obsesionante para el ofendido marido, que los repite varias veces, como descubridores de su deshonra y acicate de su venganza. El prosista resumió la comedia y al llegar el momento de patética intensidad dramática, no supo, o no quiso, desprenderse de la rima. Coincidencia análoga se halla al tratar del motivo que tuvo el Veinticuatro para matar al papagayo "pues hablaba y no me dijo mi afrenta" que se repite casi a la letra en la relación. Queda pues patente que no fué la relación prosística fuente de la comedia, sino trasunto de ella. De todos modos tampoco nos aclararía la fecha, pues la relación es posterior al romance de Juan Rufo al que cita taxativamente, alabando de elegantes sus versos ${ }^{79}$.

El dato más firme nos lo dió el afanoso investigador Pérez Pastor publicando un documento ${ }^{80}$ en que se solicita permiso para representar en Navalcarnero la comedia de Los Comendadores el 9 de julio de 1593. No sé por qué esta fecha no ha tenido buena acogida; seguramente que a haber estado publicado el documento cuando Menéndez Pelayo escribió su ilustrativo prólogo de la comedia no hubiese despreciado el dato. Dan en suponer que esa comedia que se había de representar en Navalcarnero no sería la que conocemos de Lope, sino la de otro autor ${ }^{81}$. Otros piensan que acaso la forma original no incluía los apasionados sonetos. Todo es posible, pero mientras no conozcamos esa hipotética obra precursora, no tenemos por qué rechazar que fuese la de Lope la solicitada en 1593 , sólo en tres años anterior a la fecha hasta ahora preferentemente aceptada. En cuanto a los sonetos tendremos ocasión para suponer que fueron escritos en Alba, es decir, antes de 1596.

No se puede hablar de cronología de comedias de Lope sin acudir a los estudios esmeradísimos que los señores Morley y Bruerton han consagrado a ese asunto. Su última palabra ${ }^{82}$ respecto a Los Comendadores es la fecha 1596. Apoyan su razonamiento en que el romance fuente

78 Obras dramáticas escogidas de Lope de Vega, vol. Ill, pág. xxv.

79 También Gracián alabó los versos del romance de Juan Rufo tomándolos por ejemplo de exquisiteces en sus obras Agudeza y arte de ingenio, ed. 1664, págs. 119 y 230 y Discurso V.

${ }_{80}$ Nuevos datos acerca del histrionismo español, pág. 36 .

81 En la Biblioteca Nacional hay una comedia ms. con el título de Los comendadores de Córdoba, posterior a la de Lope. Al parecer es una copia hecha por Claramonte de La mayor venganza de honor de Cubillo de Aragón.

$82 H R, \mathrm{XV}$, pág. 57. 
apareció en I 596 y que el soneto autógrafo corresponde a esa misma fecha. Ya hemos visto que el romance puede afirmarse que existió antes de la edición en que hoy le conocemos y en cuanto al soneto dedicado a doña Antonia sabemos que no es la versión primitiva.

Si acudimos a los esquemas estróficos que han proporcionado tantos aciertos a los mencionados especialistas, el único tropiezo que encontramos es la introducción de la décima que no se encuentra, decían, en comedia fechada de Lope hasta 599 en El Argel fingido. Hoy sabemos que $E l$ remedio en la desdicha tiene décimas y está fechado en I $596^{83}$. Bien pudo Lope usarlas tres años antes en su comedia, tanto más que por entonces las prodigaba en su novela La Arcadia ${ }^{84}$. Además ha de observarse que se emplean esas décimas (sólo 4) en el soliloquio del Venticuatro y cada estrofa termina a modo de estribillo con los dos versos obsesionantes "Si a tu mujer se lo diste..." Son pues una décimas como las empleadas en las glosas. El soliloquio termina con una redondilla. No hay pues ningún inconveniente para aceptar la fecha I593 para la composición de esta comedia.

Los investigadores que han estudiado comparativamente las poesías líricas de Lope, y en especial los sonetos, que se encuentran en las comedias y en otras obras suyas, llegan a la conclusión de que las versiones del teatro son más antiguas. Este criterio, con no pocas excepciones, es cierto, pero no lo es menos que esos versos brotaron muchas veces en un clima de intimidad pasional y que luego el autor se los prestó a las personas dramáticas, y así nos dice el mismo Lope:

... El poeta no es posible que escriba con afecto y con blandura sentimientos de amor, si no lo tiene, y entonces se descubren en sus versos cuando el amor le enseña los que escribe ${ }^{85}$.

Leyendo los dos sonetos citados de Los Comendadores pensamos que no los inspiró Talía, sino la musa viva, cuya hermosura le traía por entonces enajenado sin alcanzar su posesión, a la que cantaba en sus versos con el nombre de Celia.

Esta Celia dejó también rastro en obras que Lope consideraba de más empeño que sus canciones y su producción dramática y que elaboraba con mayor esmero, sin el apremio de los representantes que le obligaban a componer sin cesar comedias nuevas o rematar precipitadamente las que tenía de largo tiempo proyectadas.

83 A. G. DE Amezúa, Una colección manuscrita y desconocida de comedias de Lope de Vega.

${ }^{84}$ Lope usa el nombre décima en la novela Arcadia (pág. 55), y sigue empleando ese metro en las págs. 136, 214, 259, 268, 332 y 376 . (OS, vol. VI).

${ }^{85}$ Lo fingido verdadero. Acad, vol. IV, pág. 58 b. 
El año de 1598 es de capital importancia para la obra y la vida de Lope de Vega. Con motivo de la muerte de la Duquesa de Saboya, doña Catalina, hija de Felipe II, ocurrida en noviembre de 1597, se manda suspender las representaciones escénicas. Los enemigos del teatro, principalmente teólogos, aprovechando la ocasión, arrecian en sus ataques. El rey, previo un informe que pide al arzobispo de Toledo, al confesor del príncipe y a otros secuaces, dicta un decreto prohibiendo las comedias (mayo i 598). Muerto Felipe II en setiembre del mismo año, Madrid y otras ciudades suplican al nuevo monarca que permita las representaciones, y en 17 de abril de 1599 se da la orden de reposición de las comedias con ciertas restricciones.

No duró mucho la prohibición, pero Lope, que vivía de la producción escénica, sufrió duro quebranto, agravado porque en aquellos días (abril 25 de 1598 ) había contraído segundas nupcias con doña Juana de Guardo. Este matrimonio es uno de los enigmas en la vida de Lope y al que hasta hoy no encontramos explicación en alusiones de las obras del poeta tan aficionado a contarnos incidentes de sus amores más o menos a las claras. Únicamente en la epístola a Gregorio de Angulo de hacia 1605 , en un breve resumen que en dos tercetos hace de su vida, manifiesta lo poco satisfecho que está de aquel matrimonio:

Cegome una mujer, aficioneme, perdóneselo Dios, ya soy casado; quien tiene tanto mal, ninguno teme ${ }^{86}$.

Ese ya tiene que referirse al momento actual. Podríamos hacer una conjetura sin base segura. Acaso Lope cortejó a doña Juana y pasó de lo permitido, como había hecho con doña Isabel y con doña Antonia; pero en esta ocasión existía un padre enérgico, un abastecedor de la villa, que no necesitó acudir a la Justicia para obligar al poeta a que cumpliese con su obligación. En compensación le ofreció una dote, que nunca pagó.

En el interregno que sufrió el teatro, se dedicó Lope a publicar obras no dramáticas, las que consideraba de mayor importancia; parecer que la posteridad no ha compartido. La primera obra que dió a la estampa fué La Arcadia ${ }^{87}$, novela pastoril escrita en su mayor parte en Alba, cuya artística corte ducal sirve de escenario. Nuestro poeta, para agradar a su señor el duque don Antonio, escribió durante el tiempo que estuvo a su servicio, una serie de composiciones (varios romances, un poema descriptivo, una égloga y dos comedias) en las que convirtió en materia poética la extraña aventura de las dúplices bodas que fueron

86 OS, vol. I, pág. 420.

${ }^{87}$ Octubre 1598. Es curioso que Lope y Cervantes estrenaran la imprenta con una novela pastoril: influjo de la moda. 
causa del largo proceso contra el Duque. Terminada la novela ya en Madrid, y cuando Lope decidió dedicarla al Duque de Osuna, se vió obligado a cambiar el desenlace amoroso que había dado a las otras obras inspiradas en el mismo tema, y degeneró al final en una enojosa obra didáctica.

Espera La Arcadia una edición esmerada que nos tiene ofrecida el insigne lopista Amezúa y bien merece un detenido estudio que ilustrará lo que ha dado en llamarse, sin analizarlo, primer estilo de Lope. Aparte de lo que representa $L a$ Arcadia dentro del género de la novela pastoril, tiene especial importancia el riquísimo vocabulario, las preciosas comparaciones que rara vez alcanzan el brío de la complicada metáfora, y el uso de tanta variedad de metros. Además, también vale la pena estudiar la silueta trazada con rasgos indelebles de varios personajes reunidos en aquella mansión de Alba.

Mi propósito es sólo tratar de esa novela para observar la pareja Celia-Belardo que no podía faltar entre aquellos pastores que en verso y prosa suspiran padeciendo de amor. La primera composición que encontramos dedicada a Celia es el soneto que canta el pastor Celso: "Si la grana del labio Celia mueve" ${ }^{88}$, en que ensalza las perfecciones de la amada. Es de los poco afortunados de la novela, con una serie de comparaciones, menos expresivas que de costumbre, y una larga recapitulación que ocupa los dos últimos versos. Este recurso poético se halla muy repetido en La Arcadia. El soneto tiene traza de ser interpolación tardía, pues no está ligado con lo que le precede ni con lo que sigue, sino recitado a destiempo interrumpiendo el relato.

Belardo más adelante se representa "pastor pobre, con poca costa y mucha traza, que suele ser arbitrio de los que pueden poco". Asiste a un torneo acuático y lleva por letra: "Pobreza y alas, teneos, / que es ir al bien por rodeos", versos que nos recuerdan al "teneos deseos locos" del soneto de Los Comendadores. Sigue Lope, como en su primera juventud, lamentando su humilde estado. Ganó Belardo en combate con el rico Laureo un corazón de marfil con las flechas de oro y se lo dió a Celia, porque "si ganara más [corazones] que tiene estrellas el cielo, sin duda se los diera todos".

La canción más importante es la que dedica Belardo agradecido al regalo que le ha hecho Celia de una higa de cristal guarnecida de ${ }^{\circ}{ }^{89}$. No hay para él nada como amar su hermosura. Confiesa a todos que es ella el solo bien que estima; en quererla ocupa todo el sentido y muere si se aparta un punto de verla. El mayor premio de sus penas será contemplar aquellos ojos celestiales; es prisionero de sus cabellos rizos, la boca que alegra, la frente de nieve... Hará inmortal su hermosura si merece la pluma levantarse hasta su gloria.

Aparte de darnos aquí un retrato de Celia, tenemos muchos concep-

${ }_{88} O S$, vol. VI, pág. 228.

${ }^{89} O S$, vol. VI, pág. 273 
tos iguales a los del soneto de Los Comendadores: "Ya no quiero más bien..." Está todo más diluido, cual conviene a la diferencia obliga da entre una larga canción en octavillas encadenadas de octosílabos pareados y la concisión propia de los 14 versos del soneto. Esta composición nos confirma que a Celia estaba dedicado el soneto de Los Comendadores.

Al final de la novela y a modo de colofón viene un soneto de "Celia y Belardo". Es una queja de que él acierta a pintar ajenas desventuras, y con ingratitud calla las propias. Claro que estos versos, como acontece en casos análogos, son del propio Lope.

En la edición de la novela ${ }^{90}$ de 1602 , se añade al fin un soneto del poeta valenciano Carlos Boyl, gran amigo del Fénix. Trata del rigor que Celia, "de beldad dechado" usó con Belardo "siendo un pastor sabio y gallardo" 91 . Cómo explicar que en 1602 , el mismo año en que publica las Rimas, con los múltiples sonetos en que preside su encendida pasión por Lucinda, siga proclamando su amor a Celia? La hermosura de Angélica nos aclarará esta aparente incongruencia. Pero antes examinemos el sentimiento erótico de Lope a través de otras obras que aparecieron con anterioridad.

Al final del mismo año i 598 publicó Lope otra obra muy de actualidad: La Dragontea, poema en 720 octavas dedicadas a cantar la última derrota y la muerte del terrible pirata inglés Francisco Draque, ocurrida el año anterior. Hoy, aunque no carece de excelentes octavas, es obra enojosa de leer, pero respondía entonces al regocijo que sintieron los españoles al ver desaparecer a aquel implacable enemigo que perseguía y robaba nuestras naves en aguas de España y de América ${ }^{92}$.

90 Impresa en Valencia, I602.

91 Este soneto falta en la mayor parte de las numerosas ediciones que atestiguan el éxito de la Arcadia. Como no se incluye en las $O S$, donde se utilizó la ed. de I6II, lo reproduzco aquí:

Si fuiste por tu Celia, Lope amigo, transformado en pastor dicho Belardo, también yo de Menandra el premio aguardo, que su Lisandro fui y su luz sigo.

No me pienso quexar si no la obligo, pues siendo tú un pastor sabio y gallardo, los disfavores que conmigo guardo, no llegan al rigor que usó contigo.

Yo sé bien que Alexandro no te diera, a ser Diógenes tú, el segundo grado, que tu valor al suyo prefiriera.

Y sé que Celia, de beldad dechado, conociendo su engaño, conociera que eres tú solo de los dos traslado.

${ }_{92}$ Tan popular era el nombre de aquel corsario que las madres amenazaban a los niños diciendo "que viene el Draque" como si fuese el Coco. Todavía en I6 I7, 20 años después de muerto el inglés, usa Lope del nombre como si fuese 
La fecha de la primera edición de esta obra aparece dudosa porque algunos críticos dijeron, sin haberla visto, que se publicó en Madrid. Dió pie a esta afirmación el que Antonio Sancha en 1776 en las Obras sueltas de Lope de Vega da noticia de un manuscrito de su propiedad que tenía la aprobación de Pedro de Padilla fechada en el Monasterio del Carmen de Madrid en 9 de diciembre de $1597^{93}$. Sin embargo no se conoce una edición de Madrid de esa fecha, sino la de Valencia donde no apareció hasta 1598 con otras dos aprobaciones más, fechadas en el mes de abril. El asunto se aclara gracias a un memorial descubierto por Rodríguez Marín ${ }^{94}$ en el cual el cronista Antonio de Herrera advierte en I 5 de febrero de 599 que "Lope de Vega compuso La Dragontea ... en que se contiene lo sucedido a Francisco Draque cuando fué resistido en Tierra Firme, siendo capitán don Alonso de Sotomayor, a donde cuenta aquel suceso muy en contrario de la verdad, con manifiesto agravio de las personas que allí intervinieron". No habiéndosele dado licencia en Madrid, publicó el poema en Valencia, y ahora pedía de nuevo autorización. No se le debió conceder por el momento y no conocemos nueva edición hasta i 602 que se publicó en un volumen con las Rimas y $L a$ hermosura de Angélica ${ }^{95}$. Lleva un prólogo de don Francisco de Borja, Comendador Mayor de Montesa, en que se afirma que los diez cantos "están sacados de la relación que la Real Audiencia de Panamá hizo y autorizó con fidedignos testigos". Pero el verdadero motivo de la persecución no consistía en la falta de verdad histórica, leve tacha para tma obra poética, sino en que Lope en su poema hizo héroe de la resistencia que se opuso a los ingleses a don Diego Suárez de Amaya, prefiriéndole al capitán general don Alonso de Sotomayor ${ }^{96}$. En consecuencia se dió la orden de que no entrasen en el Nuevo Mundo ejemplares de La Dragontea, con lo cual perdió el mercado de América donde se hubiera leído con el mayor interés ${ }^{77}$.

del demonio cuando dice al Duque de Sessa, quien no ha querido irse de veraneo por no alejarse de su amante: "No hay sino pasar lindo verano, cenar y holgarse y váyase al Escorial el Draque" (Epistolario, vol. III, pág. 321).

${ }^{33} O S$, vol. III, pág. II.

94 Nuevo datos para las biografias de cien escritores de los siglos xvi y xvii, pág. 69 .

95 La bibliografía de las obras no dramáticas de Lope de Vega está por hacer y las ediciones de las Rimas, que fueron múltiples, se prestan a muchas confusiones porque su contenido es muy variado.

${ }_{96}$ En 1620 salió a luz una Relación de los Servicios que hizo a su Majestad D. Alonso de Sotomayor, por Francisco Caro de Torres, que fué a modo de compensación de la supuesta injusticia cometida por Lope de Vega "el cual movido de la primera información atribuyó la gloria del suceso a quien no le tocaba, quitándola a quien de derecho se la debe". Lope, acaso por ligereza, no se dió cuenta de la importancia de Sotomayor y no le hace intervenir en la defensa de Panamá hasta los dos últimos cantos y de una manera episódica.

${ }^{97} \mathrm{La}$ malevolencia sigue persiguiendo a La Dragontea; todavía en 1912 en un estudio que precede a la edición de La Argentina de Barco Gentenera, al 
El asunto de este poema y su desarrollo parecía alejarle de intromisiones eróticas; pero el poeta no puede menos de enterarnos de cuál era su estado de ánimo en aquel momento. Comienza el canto Iv $^{98}$ con una imprecación general al Amor y tras de ella esta octava de carácter personal:

Pasó la primavera de mis años;

lo que he dejado, miro con vergüenza, y al blanquear los mismos desengaños parece que otra vez tu ardor comienza. Pero ¿dónde me llevan tus engaños? ¿Qué importa que me deje o que me venza? No soy yo, Amor, que una mujer hermosa está de tu mudanza querellosa.

Pero aquí no es él quien se queja, sino una mujer hermosa. No es aventurado suponer que sería la bella de ojos azules quejosa de la boda del poeta que apartó, aunque por poco tiempo, a los dos amantes.

Al final del canto vin, después de colmar de elogios a personajes, casi todos de la nobleza, que cultivaban las letras, nos encontramos con una octava que no tiene hilación con lo que precede.
$\mathrm{Y}$ si de aquel $\mathrm{mi}$ peregrino objeto recogiere algún tiempo la gran suma, que dirigida al celestial sujeto no es justo que el olvido la consuma, de su hermosura y mi amoroso efeto cuanto cantado hubiera lira y pluma ha de venir donde el amor me dice que su nombre y mi fe se inmortalice ${ }^{99}$.

Un tanto oscuro es el pasaje, pero descubrimos aquí el propósito de recoger la gran cantidad de versos que había dirigido a su amada, para que la fe de él y la hermosura de ella fuesen inmortales. Los tres concepto perennes que guían su obra: Amor, Belleza y Fama. La recopilación de aquellos versos constituye la parte más apasionante de las $R i$ mas donde tantos sonetos de amor han alcanzado la inmortalidad de que tan seguro se mostró siempre el poeta.

Pocos meses después de imprimir La Dragontea, publicó Lope a

hablar del contento que sintieron los españoles al desaparecer aquel Dragón de los mares se lee este sañudo juicio: "En intérprete de las pasiones bajas del pueblo español se constituyó el más abundante y afamado de sus poetas escribiendo $L a$ Dragontea, poema repugnante por los sentimientos enconosos que respira..." El prologuista presta más atención a la hispanofobia que a adquirir datos históricos; involucra los hechos, ignora la cronología y hasta equivoca la fecha de la derrota de la Invencible, que tanto goce le produce.

$98 O S$, vol. III, pág. 244 .

99 La Dragontea. OS, vol. III, pág. 337. 
comienzos de 1599 El Isidro, poema que comenta la vida y milagros del bienaventurado labrador a quien Madrid veneraba por santo mucho antes de su canonización ${ }^{100}$. Según sabemos por carta de Fray Domingo de Mendoza $^{101}$, Lope había of recido empezar a escribir este poema en el verano de 1596 "y que pensaba guardar en su composición la gravedad, gusto y preñez de nuestras castellanas y dulces redondillas". En el prólogo hace su autor el elogio de los versos cortos castellanos, comparándolos con los metros italianos "más largos y licenciosos" y añade: "yo sé que algunos italianos envidian la gracia, dificultad y sonido de nuestras redondillas" ${ }^{102}$. Al comienzo del poema se justifica de usar los versos humildes castellanos y termina declarando que ha tenido gran trabajo "en proseguir historia en verso que ha de tener las consonantes y la sentencia tan juntos que mil veces me viera arrepentido". Efectivamente, se nota en algunas estrofas el esfuerzo de sacar a luz la preñez de esas coplas, la dificultad de encerrar los conceptos en breves versos con rima obligada.

Ha de observarse que no se usa aquí el nombre de quintilla, que es el que damos a esas estrofas de 5 versos octosílabos, ni lo nombra Lope en el Arte nuevo (1609) ni en la Justa poética de la beatificación de San Isidro (1620) ni en otras ocasiones en que enumera diversas clases de metros. ${ }^{103}$.

En este largo poema en que abundan las digresiones no podía faltar espacio para manifestar su íntimo estado pasional. El canto vir comienza con unas quejas al amor.

100 Fué beatificado en 1620 y canonizado en 1622 .

101 Este dominico tenía reunidas las probanzas para la beatificación del Santo y se las comunicó a Lope. $O S$, vol. XI, pág. XXI.

${ }^{102}$ Este elogio de los metros castellanos lo repite a lo largo de su obra, tanto más cuanto arrecia su censura al culteranismo. En El Laurel de Apolo (1629) escribe:

Aquí las redondillas admiradas de Italia, nuestra lengua ennoblecieron que, como castellanas, no sufrieron ser de phrasi estranjera adulteradas: éstas, como doncellas recatadas, huyen culteranismos, porque sólo permiten hispanismos y acabar por contrarios, si bien términos varios, como vemos que suena bien, mal, amor, olvido; gloria y pena.

103 Rengifo en su Arte poética española (dedicatoria al Conde de Monterrey en 1592) tampoco usa la voz quintilla, y define la redondilla como copla que se compone de 5 versos; luego habla de otra redondilla que consta de 4 versos. Tampoco en Cervantes se halla la palabra quintilla. (Véase Quijote ed. de Rodríguez Marín de 1928, vol. IV, pág. il 8 n.). Covarrubias en su diccionario trae: "Quintillas, coplas redondillas de 5 pies, cinco versos". 
Amor, ¿quién te trujo aquí, cuando más lejos, tirano, estaba mi pluma y mano de mezclar aquí por ti lo divino a lo profano...

Duro hado, estrella fiera, más que influencia, castigo; ¿qué es esto, enemigo fiero, que de cualquiera manera tenga de encontrar contigo?

¿Qué fuerza, qué industria y arte podrá librarme de darte este tributo algún día?

¿Que no ha de haber cosa mía en que tú no tengas parte!

Déjame en este sagrado, que goce se me conceda que de ti librarme pueda: basta lo que te has llevado, no vuelvas por lo que queda.

Al principio prometí cantar, fiero Amor, sin ti; ${ }^{104}$ déjame seguir mi estilo y no me rompas el hilo con que de Creta salí...

Nací amando, y cuantas veces el día infausto me ofrece, vuelve aquella ardiente furia, y para mayor injuria mi vida mengua y tú creces $^{105}$.

Esto lo escribía a fines de 1598 , pero no sería inspirado por su mujer legítima, sino por un amor furtivo que le inquietaba y era causa de amargos desengaños. Algo aclaran los versos siguientes; que inspirados, según dice, en León Hebreo, los aplica a sí mismo:

De amor y apetito odioso

deleite es el fin que veo, mas difieren en deseo, que amor lo tiene en lo hermoso $\mathrm{y}$ el apetito en lo $\mathrm{feo}^{106}$.

El relato que un soldado menesteroso hace a Isidro de las desdichas

104 A pesar del propósito de no hablar de amores, ya había insertado (pág. 183) un trozo de égloga en que intervienen los mismos personajes que en otras composiciones pastoriles suyas: Silvia, Jacinto, Tirsi, Menalca.

$105 O S$, vol. XI, pág. 193.

106 Esta misma idea, ampliada, la desarrolla más tarde en una escena de $L a$ doncella Teodor en que cita a Aristóteles (Acad, vol. XIV, pág. ${ }_{3} 8$ ). 
amorosas que le habían acaecido nos parece a primera vista un trozo autobiográfico de las primeras aventuras del propio Lope, pero una quintilla con la curiosa alusión a los romances moriscos escritos entre I $_{583}$ a $5^{88}$ nos hace pensar en que el narrador representa a alguno de los contrincantes de nuestro poeta.

Quitóme otro amor los bríos

después de mil desafíos,

trofeos verdes y azules

de Zaides y de Gazules,

moros enemigos míos ${ }^{107}$.

No hay que perder de vista que Lope no sólo literaliza su propia vida, sino también la de las gentes que le rodeaban, desde Melchor de Prado, Vargas Manrique, Liñán de Riaza, compañeros de aventuras en su mocedad, hasta su señor el Duque de Alba y don Diego de Toledo y otros, respecto a los cuales descubrimos noticias literario-biográficas a medida que vamos conociendo sus vidas efectivas. Claro es que sólo se apoya en algunos datos más o menos reales y luego su poderosa fuerza imaginativa los eleva hasta la creación de la obra poética.

En el mismo año de 1599 publica Lope las Fiestas de Denia, larga relación de las que el Duque brindó al rey Felipe III y a la princesa Isabel Clara Eugenia cuando se dirigen a Valencia para recibir a sus respectivos prometidos, Margarita de Austria y el príncipe Alberto. Consta la obra de 192 octavas y está dedicada a la ausente Condesa de Lemos, virreina de Nápoles, hermana del Duque de Denia y madre del Marqués de Sarria a cuyo servicio había ido Lope.

No parece que nuestro poeta asistió contento a los festejos porque se ausentaba celoso de su cuidado. Por dos veces alude a su disgusto:

No me permite Amor, que fué castigo del cielo en mí desde mis años tiernos, y sin remedio ha de vivir conmigo, después de muerto yo años eternos, hablar mucho de Marte su enemigo, cuando sus celos son, o mis infiernos, por quien en tantas fiestas como canto nube me vuelve junto al mar mi llanto.

Y termina repitiéndose víctima del amor:

Señora, perdonad si no he pintado con más sutil pincel tan ricas fiestas que este mi dulce e inmortal cuidado

107. $O S$, vol. XI, pág. I 7I. Zaide y Gazul se llamó Lope en los primeros romances moriscos que escribió en su juventud. 
me tiene vida y alma descompuestas;

para un celoso ausente y olvidado las mejores del mundo son molestias, que a donde todo el mundo alegre vino, yo solo fui llorando peregrino ${ }^{108}$.

La hermosura de Angélica es la obra capital de las terminadas por Lope en aquel fin de siglo ${ }^{109}$. En el prólogo nos dice el autor que escribió esta obra entre jarcias del galeón San Juan "en una jornada de mar donde con pocos años iba a ejercitar las armas". Aunque entre aquí por mucho su jactanciosa fantasía, bien puede admitirse el año i 588 en que se embarcó en la gran Armada contra Inglaterra como fecha en que comenzó el poema. En octubre de I 598 lo daba por acabado cuando otorgó poder al impresor Várez de Castro para que obtuviese las licencias de publicación.

Desde luego La Angélica revela una larga elaboración y cuando la publicó en 1602 , las variaciones que había introducido no se limitaron a "la última lima" como nos dice el poeta, sino a muchos lugares de la composición. Una parte de la obra la escribió indudablemente en Alba como lo prueban unos versos en que se dirige al Duque don Antonio, llamándỏle "Señor mío" y "mi dueño", lo que no haría si ya hubiese dejado su servicio ${ }^{110}$.

Lope, según su costumbre, intercala en el complicado relato porción de alusiones autobiográficas, como hemos indicado al tratar de la supervivencia del recuerdo de Elena ${ }^{111}$. No faltan algunos versos de emoción inspirados por Isabel, aunque luego aplicados a distinto sujeto. De Celia nos proporciona un retrato en dos octavas al final del libro III.

Celia, reina de Córdoba famosa, como el aurora se mostró serena, cándida, fresca, limpia y olorosa más que el jazmín, mosqueta y azucena; con vivos ojos, cuya luz hermosa fué para tantas almas gloria y pena, graciosa boca, dientes, habla y risa, garganta al torno, blanca, altiva y lisa.

Diferente en el traje de Nicandra, los pechos descubrió, que siendo nieve pudieran abrasar la salamandra

108 OS, vol. III, págs. 403 y 428 .

${ }^{109}$ OS, vol. III, pág. XIII.

110 Pág. 235.

111 Observaré aquí de pasada que los versos iniciales del poema están dedicados a Elena, y no a Lucinda como algunos han sospechado, pues sólo a aquella amada de quien acaba de apartarse puede decir el alma "de quien fuiste dueño", "aquel humilde ingenio que os consagré desde mis tiernos años" y llamarla "causa fatal de mis dichosos años". 
que entre las llamas a vivir se atreve;

con un alma tan rica y alejandra

que de mi voto el precio se le debe;

y si hablara, sin duda se le diera,

que hablando más que Angélica lo fuera ${ }^{112}$.

Tenemos aquí los mismos rasgos con que el poeta nos había antes descrito a Celia en La Arcadia y en los sonetos y canciones: vivos ojos, graciosa boca y risa, pechos de nieve, habla encantadora ..., de tal modo que por su voto se le debía dar el premio de la hermosura, sin esperar a Angélica.

En el canto $\mathbf{v}$ nos presenta un doble de este retrato. El relato se interrumpe en el momento en que le fué discernido el premio a Angélica para advertirnos que de haber sido su contemporánea Lucinda, ésta hubiese resultado vencedora:

Si en aquella famosa edad vivieras, hermosura inmortal, bella Lucinda, ¿quién duda que de Angélica vencieras la que hoy con el tercer planeta alinda? Tú sola el justo premio merecieras, $\mathrm{y}$ aun es razón que su laurel te rinda conociendo que haberle merecido fué por no haber tu oriente amanecido.

Que si mostraras esos ojos bellos, azules como el cielo y los zafiros, de donde amor, aunque se abrasa en ellos, hace a las almas amorosos tiros: si mostraras la red de tus cabellos, dulcísima prisión de mis suspiros, que los excedo, si en amarme calmas, y ojalá que suspiros fueran almas.

Si mostraras la boca envuelta en risa, la blanca mano y el nevado pecho basa de la columna tersa y lisa en que se afirma aquel divino techo; sospecho que bajaran tan aprisa almas como laureles, a despecho de tantos pretendientes; pero ignoro quién fuera de tus méritos Medoro ${ }^{113}$.

Una vez más nos encontramos con la bella de ojos celestiales, de boca risueña y de nevado pecho, retratada ahora en versos más vehementes y acendrados, y a la que el poeta otorgaría asimismo el premio.

La conformidad de los retratos y el considerar el poeta merecedoras

112 OS, vol. II, pág. $4^{8}$.

${ }^{113}$ Loc. cit., pág. 65. 
del premio a la par a Celia y a Lucinda nos hace sospechar que se trata de la misma persona, aquella que en la realidad era Micaela Luján. Insisto en dar importancia a la similitud de los retratos porque Lope nos ha dejado sendas pinturas de sus amadas con rasgos tan precisos que nunca se confunden unis con otras ${ }^{\mathrm{I14}}$. Entre los versos preliminares de La Angélica se encuer ran dos redondilas a nombre de Lucinda, la que expone sus quejas al poeta, como había hecho Celia en el soneto que se le atribuye al final de La Arcadia. Otro rasgo común a las dos representaciones de una misma amada ${ }^{115}$.

El cambio de nombre no es óbice para la identificación de una misma persona, puesto que es corriente que los poetas llamen a sus amadas de varias maneras. No sabemos cuándo Lope dejó de usar el nombre de Celia; seguramente coexistiría algún tiempo con el de Camila, anagrama casi perfecto de Micaela, y el de Camila Lucinda y por fin acabó por predominar el segundo elemento.

No es mi objeto tratar aquí de los innumerables versos que dedicó Lope a ensalzar a Lucinda, pues bien conocidos, y en buena parte estudiados, están los bellísimos sonetos de las Rimas y la canción "Serrana hermosa..." en la que descubre lo más íntimo de su sensibilidad, haciéndonos acompañarle paso a paso en el desgarramiento de su corazón según va dejándose atrás las luces de la ciudad, el rumor del río . . i Qué lejos estamos de aquella retórica despedida "de vos me aparto y quedo"!

Nada de esto nos sirve para aclarar del todo el enigma de Celia, aunque hemos señalado algunos sonetos anteriores en que no figuraba el nombre de Lucinda hasta ser impresos en las Rimas en I602. La Jerusalén nos dará mayor luz.

Este largo poema de La Jerusalén conquistada fué compuesto lentamente durante siete años. En el prólogo de las Rimas de I6o2 dice Lope al lector "Presto (si Dios quiere) tendrás los xvi libros de mi Jerusalén". Luego el número de libros ascendió a 20 y en I605 daba Lope por terminada la obra, y a su satisfacción, según carta que el $6 \mathrm{de}$ setiembre escribe al Duque de Sessa: "Mi Jerusalén envié a Valladolid

114 Lope caracterizó la figura de Elena en multitud de obras y muy especialmente en La Dorotea: ojos verdes y pintados (con pintas, ojos de malaquita) algo desvergonzados, que antes que los enviden, quieren, cejas y pestañas negras, la boca risueña, aunque no le dan causa, la tez trigueña clara, el talle esbelto y la mano larga. Este fué durante bastantes años el ideal de tipo femenino y con estos rasgos nos presenta en un soneto la perfección con que salió Eva de manos del Creador, y en otro soneto la humanal belleza de María Virgen. La hermosura de Micaela es bien distinta, toda para saciar los sentidos, espléndida de formas, ojos azules como el cielo, cabellos rizos, tez blanca y rosada, pecho de nieve, voz angelical. Doña Marta tiene ojos verdes esmeraldinos, no los de Elena, de mirar honesto, cabellos rubios y la mano no larga, las dotes intelectuales muy superiores a las de anteriores amadas y capaces de mayor atractivo para el poeta en edad ya muy madura.

$115 O S$, vol. II, pág. xxt. 
para que el Consejo me diese licencia; imprimirela muy aprisa ... Es cosa que he escrito en mi mejor edad y con estudio diferente que otras de mi juventud donde tiene más poder el apetito que la razón"116.

La impresión no se hizo tan aprisa, pues no obtuvo licencia hasta I 608 y al publicarse en i6o9 explica Lope en el prólogo al Conde de Saldaña el retraso: "Tarde y esperada sale a luz, que por ocasión de algunos libros sin doctrina, substancia y ingenio escritos para el vulgo, se prohibieron todos" 117 .

Al parecer no se añadieron episodios después del año i605. Anteriores a esa fecha podemos señalar unos versos de desahogo contra el Amor muy análogos a los que hemos citado de La Dragontea y El Isidro y que revelan una depresión de ánimo ${ }^{118}$. Si tomamos al pie de la letra la indicación cronológica que contiene, debió de escribirse ese trozo hacia I6oo, cuando Lope tenía $3^{8}$ años, por lo tanto casi al mismo tiempo que esos otros dos poemas.

Aquí si la trompeta belicosa que de Belén sobre los campos miro, diera lugar o fuera mi argumento, cantara yo de Amor el instrumento. Perdona niño, más que el tiempo cano, que me han cansado ya tus desvarios; templando voy aquel Argel tirano,

110 Epistolario, vol. III, pág. 6.

${ }_{112}$ Lope no dejó de tener dificultades para dar al público sus obras. Ya hemos visto lo que ocurrió con La Dragontea.-En 1598 da poder para gestionar las licencias a fin de imprimir La hermosura de Angélica, pero no se publica hasta 1602.-El ms. autógrafo de El príncipe despeñado está fechado en 1602 y lleva censura de 1607 .-En un memorial de octubre de 1608 se queja de que han mandado recoger una comedia que había escrito de la conversión de San Agustín, de lo que le había resultado grande nota en su honor y reputación. "Pide que después de borrado lo que pareciese convenir, se le devuelva para reescribirla y así quedaría restituido en su honor y buena opinión". En el mismo escrito consta la resolución de "que no ha lugar". Ha de advertirse que ya entonces era familiar del Santo Oficio de la Inquisición (Rodríguez Marín, Nuevos datos..., pág. 512).-En carta a don Antonio de Mendoza formula otra queja: "Las comedias de Alarcón han salido impresas; sólo para mí no hay licencia" (LA BARRera, Nueva biografía, pág. 654 b.).-En carta de mayo de 1610 se queja de que por rivalidades entre representantes no den licencia para una comedia suya que estudiaba Riquelme. Pide la intercesión del Duque. Epistolario, vol. III, pág. 20).La comedia de La niñez del Padre Rojas dió ocasión a que en marzo de 1620 se sometiese a Lope a un minucioso interrogatorio acerca de lo que sabía de la vida del Padre Rojas. Sin duda al tribunal eclesiástico le pareció que se había excedido el autor en el panegírico que hacía de aquel insigne varón que todos habían conocido. Así, cuando la comedia se imprimió en 1625, dice Vargas Machuca en la aprobación: "Piadosamente se cree algo de lo que aquí escribe Lope de Vega".

1ys $O S$, vol. XIV, pág. XIV. En las notas a La Jerusalén, Lope da como fuente de este trozo a Tibulo (OS, vol. XIV, pág. 518). 
oscura cárcel de los años míos;

ya en el tusón de Hermengildo hispano

y en los dioses que echándose a los ríos

del temor de Titán, se hicieron peces,

al sol he visto treinta y ocho veces ${ }^{119}$.

Vemos que entre el caos de hazañas y batallas y en la maraña de digresiones que dedica ora a hacer un resumen general de la historia de España, ora a elogiar a los escritores sus contemporáneos, no le falta ocasión para dar cabida a sus ideas amorosas más íntimas.

Cuando escribía este poema, aprovechando la situación del rey don Alfonso subyugado por la hebrea Raquel, quiere justificar el predominio que sobre él ejerce el amor ilícito, muy superior al impuesto por los lazos conyugales.

Confieso, trato, que el amor acendras, mas cuando todo fácil se descubre, ¡oh, qué tibieza, posesión, engendras!

Amor ha de ser miedo, amor recato, amor fruta cercada de altos muros, amor ha de tener algo de ingrato; no son bienes de amor si están seguros; fúndese amor, cuanto quisiere, en trato, como piensan amantes epicuros, que en no siendo amor Tántalo, no creo que tenga vivas fuerzas el deseo ${ }^{120}$.

Hállase en este poema el trozo biográfico tan conocido e importante en que presenta a Lucinda acompañada de 5 hijos. Ella cuenta a Ismenia el comienzo de sus amores. Un príncipe, codicioso de gozar su hermosura, envía a Marcelo (Lope), un labrador de "altos pensamientos", portador de ricos dones para conquistarla; pero ella despreció el oro y dió preferencia al emisario, cuyo talle y discreción la cautivaron:

No andaba amor entonces descuidado, que bien nos concertó los pensamientos, el interés del príncipe mudado en los que llama amor merecimientos: yo pienso que primero concertado fué de los celestiales movimientos, que no es posible que tan presto agrade lo que el cielo no influye y persuade.

Puso los ojos, y aun el alma puso,

$119 O S$, vol. XV, pág. 229. Nótese el modo de indicar el año por medio de metáfora y de Aries o Piscis a que tan aficionado era el poeta.

$120 O S$, vol. $\mathrm{XV}$, pág. 29 i. 
él me decía que en mis ojos bellos

en muchos versos que a su honor compuso, llamando sol azul la color dellos ${ }^{121}$.

Esta situación nos recuerda aquellos primeros romances en que aprendimos cómo Belardo se presenta ante Celia en calidad de tercero y pasa a ser su enamorado. El influjo de los astros para concertar a los amantes lo aludió en el soneto a Marcio ${ }^{122}$. La circunstancia de que el nue vo amor le sacó del alma las memorias de Elena nos la refiere más adelante cuando para aplacar los celos de Lucinda, después de confesarle aquel amor primero tan persistente, le dice:

No hay hierba o piedra que el amor resista como otro amor (advierte las historias humanas y divinas) ni pudiera vencer amor quien más amor no fuera.

Lucinda ya convencida, se entregó, y fruto del árbol del amor a que por largo tiempo ha vivido sujeta con estrechos lazos son cinco niños que esmaltan el prado. El escenario en que se desarrolla este episodio semeja evocación de un delicioso cuadro veneciano: con un fondo de tranquilo paisaje, sentadas en un prado junto a un arroyuelo que formaba mil caracolas, las dos bellas platican de sus amores. En segundo término, en sustitución de alados cupidos convencionales, aparecen tres niñas en actitud reposada y dos rapacillos traveseando, entregados a juegos propios de sus tiernos años. Escena de un realismo vivo, contemplado a través de la sensibilidad del profundo amor paternal que atesoraba el alma de Lope.

Volvió Ismenia los ojos y en el prado vió tres hermosas niñas divertidas, la mayor devanando un pardo hilado, las otras dos de la cestilla asidas, y a Lauro, ya rapaz, sobre un cayado, con dos cuerdas de lana mal torcidas haciéndole caballo, y el ameno prado midiendo, por quebrarse, el freno.

El más tierno, desnudo le seguía, y con alegre risa le animaba con una vara, y el cayado hería lo que por las espaldas le sobraba. Asido a un hilo por el pie tenía también un pajarillo que volaba, pero por ayudar al otro hermano, por el aire trocó la débil mano.

$121 O S$, vol. XV, pág. 186.

122 Véase más atrás, pág. 359. 
Conocemos los nombres de esos cinco niños por un documento de ${ }^{1} 604^{123}$ en que se enumeran siete hijos de Micaela Luján y de su marido Diego Díaz cuando muerto éste, pide ella la tutela de los menores. En este caso la maledicencia está más cerca de la verdad que el documento judicial y atribuye a Lope la paternidad de cinco de los siete hijos que allí se nombran: Mariana, Jacinta, Ángela, Juan y Félix; este último bautizado en Sevilla a 15 de octubre de I6o3 como hijo de Diego Díaz después de muerto éste en Cartagena de Indias en enero del mismo año.

La mayor dificultad con que tropezamos para identificar a Celia con Lucinda estriba en que hasta ahora se ha sostenido que las relaciones de Lope con Micaela no habían empezado hasta I599. Veamos en qué se funda tal afirmación. Rodríguez Marín descubrió en unos documentos sevillanos de 1603 y i604 que Lope anteponía a su firma una M, que era la inicial de Micaela, quien por entonces le traía embelesado ${ }^{\mathbf{1 2 4}}$. Esa M la encontró Américo Castro en comedias autógrafas fechadas entre I 602 y I 608, y no sólo va la inicial antepuesta a la firma, sino enlazada en varias rúbricas, señales de que Micaela era una obsesión. En un poder otorgado en octubre de 1598 la firma de Lope va precedida de las iniciales J. G. que corresponden a Juana de Guardo con quien en abril había contraído segundas nupcias. Pareció que esta unión excluía el trato con Micaela; como si Lope hubiera escrupulizado el asistir a dos mujeres a un tiempo. Igualmente en un documento notarial de I 594 firmaba anteponiendo la inicial de su mujer Isabel, cuando ya estaba perdidamente enamorado de Celia. De todos modos se tomó la fecha del citado poder como base para decir que hasta después de I 598 no se enamoró Lope de Micaela.

E1 mismo Américo Castro enumera hasta una docena más de comedias en que se desliza más o menos furtivamente el nombre de Lucinda, solo o acompañado del de Belardo, alusión indudable a Micaela. Esas comedias no llevan fecha, pero como según Castro el trato amoroso de Lope con Micaela fué a partir de I 599, ninguna de esas comedias, se dijo, puede ser anterior. Tal afirmación se basaba en una hipótesis, pero hizo fortuna y ha sido aceptada por cuantos han tratado este asunto. El ilustre lopista Courtney Bruerton, que ha añadido a la lista de Castro algunas comedias más del tipo Belardo-Lucinda, llega a la conclusión de que cualquier obra en que haya clara referencia a Micaela no es anterior a I 599. Ninguna obra fechable antes de $\mathrm{I} 599$ contiene ese personaje ${ }^{125}$. Naturalmente, como que a cuanta comedia contiene el nombre de Lu-

123 Fué hallado por Rodríguez Marín, $B A E$.

$124 B A E$, I, pág. 472. Lope alude a esa costumbre en la comedia El dómine Lucas de 1593. (AcadN, vol. XII, pág. 75 a). También menciona ese uso en una carta al Duque de Sessa: "A mi me sucede lo que a los que firman con el nombre de lo que aman en la primera letra" (Epistolario, vol. IV, pág. 10).

${ }^{125} H R, \mathrm{~V}$, pág. 312. 
cinda se le asigna desde luego el año I 599 como término a quo. Y lo más curioso es que el mismo Bruerton y su colaborador Morley, al tratar de esas comedias, llegan a prescindir del criterio cronológico que tan minuciosamente han establecido basados en la métrica, y admiten el año I 599 como punto de partida para la fechación.

Veamos otros datos más precisos. G. de Amezúa ha dado a conocer Una colección manuscrita de comedias de Lope de Vega copiadas de los originales en 1762 por Ignacio Gálvez con "escrúpulo y fidelidad", descubrimiento muy importante en datos seguros para la vida y la obra del Fénix. Algunas de esas comedias incluyen la $\mathrm{M}$ que precede a la firma de Lope, y en tres de ellas, por lo menos, la fecha es anterior a la señalada por Américo Castro: El amor desatinado (inédita) de 4 de junio de I 597, La bella malmaridada de I 7 de diciembre de I 596 y $\mathrm{El}$ caballero del Milagro con dos fechas distintas: en la cubierta dice "En Alba a ıo de noviembre de I593", y al final "a 30 de diciembre de I 593", y todavía ésta se repite en una nota del mismo autor. El año queda así bien asegurado. Pero al llegar aquí, a Amezúa le parece que la $M$ inicial ha sido "puesta caprichosamente" por el copista "a imitación de otras anteriores". ¿Por qué esta duda, siendo Gálvez un copista tan escrupuloso? ${ }^{126}$ Creo que tenemos que aceptar este testimonio y retrotraer a 593 el despertar del amor de Micaela en el corazón de Lope, esto es, el mismo año que nos sugirieron las manifestaciones literarias en que aparece Celia.

Este retroceder en unos años la intimidad del poeta con Micaela nos permite colocar con cierta amplitud la aparición de tantos hijos, fruto de aquellos amores. Se ha convenido en que la hermosa tardó bastante en entregarse y aun se dice que por lo menos se resistió hasta I6oo. Esta esquivez inspiró numerosos versos dirigidos a nombre de Celia y a veces de Lucinda. No se ha reparado en el absurdo que resulta de acumular los nacimientos de los cinco hijos, que figuran en La Jerusalén y en el documento de tutoría de Micaela, en los años comprendidos entre 1600 y 1603 fecha del bautismo de Félix, el menor de aquellos niños. Muy fecunda era Micaela, pero no tanto ${ }^{\mathbf{I 2 \tau}}$.

Para apreciar en el tiempo la producción literaria también favorece esa ampliación de fechas que evita amontonar tantas comedias fechables entre I 599, supuesta aparición de Micaela, y I603, primera lista de $E l$ Peregrino; no porque Lope no fuese capaz de escribirlas con tal rapidez, sino porque es extraño que se hayan conservado tantas obras probables

126 A partir de esta comedia no vuelve Amezúa en el "Análisis bibliográfico alfabético" a consignar la $\mathrm{M}$ en cuestión, a pesar de que sabemos por otros autógrafos que se encuentra en varias. Supongo que Gálvez, que no las copiaba por orden alfabético, no dejaría de anteponer la $\mathbf{M}$ a la firma donde la hubiese.

127 Conocemos las partidas de bautismo de Félix y de otros dos hijos de Micaela y Lope nacidos después: en I603 Félix, en I605 Marcela, en I607 Lope. 
de esos años, en contraste con la escasez de las que se aceptan de los años $1595,9^{6}$ y 97 .

La intimidad del Fénix con Micaela podemos seguirla hasta 1607 , nacimiento de Lope Félix de Vega y Luján, y prolongarla hasta i6o8 en que, al firmar la comedia La batalla del honor, antepuso el autor a su firma la $M$ denunciadora. A partir de esa fecha no volvemos a saber de Micaela; un olvido eterno la oculta. No acertamos a descubrir en los versos posteriores del poeta rastro de cómo acabó tan dilatado amor. Es más, cuando en obras tardías hace un resumen de su vida, pasa del enloquecimiento por Filis y sus desengaños, al amor torturado de doña Marta.

Una expresión dolorosa creemos descubrir en la epístola de $\mathrm{I}_{22} \mathrm{O}^{128}$, contestación a Amarilis. Esta poetisa peruana ${ }^{129}$ había oído lejanamente de Celia, amada de Lope, y a ella alude sabiendo que el poeta había celebrado "en persona de Angélica sus trenzas de oro, cejas y ojos bellos". Otra identificación más de Celia con Lucinda. Lope, que era a la sazón sacerdote, se desentiende diciendo:

Celias de solo el cielo me entretienen, no las temáis, que Celias de la tierra a ser infiernos de las almas vienen ${ }^{130}$.

Mal recuerdo conserva de la que durante tanto tiempo había sido su ídolo.

${ }^{128}$ La fecha se confirma en la misma epístola: "Marcela con tres lustros ya me obliga a ofrecérsela a Dios".

129 La existencia de esta poetisa huanuqueña no hay por qué ponerla en duda como hicieron Asenjo Barbieri, Rennert y Castro y J. Millé; la sinceridad de la epístola afirma su autenticidad. Los historiadores difieren en cuanto al apellido de la poetisa: Mendiburu (Diccionario Histórico-biográfico del Perú) la supone hermana de una doña Isabel Figueroa, casada ésta con un rico hacendado de Huánuco J. Toribio Medina (Prólogo y notas a la ed. de Arauco Domado de Pedro de Oña, pág. 11) dice acaso sea hija del poeta peruano Francisco de Figueroa. MenénDEz Pelayo (Antología de poetas hispano-americanos, vol. I1l, pág. cLXIX) elogia sobremanera la epístola y piensa que la autora, que se precia de ilustre abolengo, llevaría el apellido del capitán don Gómez de Alvarado, fundador de la ciudad de León de Huánuco. C. Oyuela abunda en la misma opinión. Sorprende que una mujer que habitaba a principios del siglo xvIII en tan apartada región peruana, frontera de indios, tuviese noticia, no sólo de la obra del Fénix, sino de sus amores. Acaso la siguiente sugestión podrá explicar el caso. Fray Diego de Hojeda, sevillano, autor del poema religioso la Cristíada, fué amigo de Lope de Vega como lo atestiguan unas quintillas de éste que figuran en los preliminares de aquella obra. Hojeda desempeñó importantes cargos en el convento de dominicos de Lima, pero luego fué perseguido por sus mismos compañeros de religión y enviado, a modo de destierro, al convento dominicano de Huánuco, donde según F. Meléndez, cronista de la orden, "murió en 1615 con fama de santo, consumido de trabajos que sufrió con admirable paciencia". Seguramente que en tan apartada región trabaría amistad el desterrado con aquella aficionada a la poesía, consagrada a Dios en "virginal estado" pero no monja, y hablarían de escritores y del mayor poeta que había entonces en lengua española. No sabemos la fecha de la epístola de Amarilis, pero desde luego estaba atrasada en punto a amores dc Lope.

$130 O S$, vol. I, pág. 476. 
En la comedia La cortesía de España de h. I6o9 hay incluido un curioso soneto muy significativo.

Quien no sabe del bien del casamiento no diga que en la tierra hay gloria alguna, que la mujer más necia e importuna la vence el buen estilo y tratamiento.

Trasladar a los brazos soñoliento un hijo en bendición desde la cuna es la más rica y próspera fortuna que puede descansar el pensamiento.

Necedad es sembrar tierras ajenas: conoce el pajarillo el huevo extraño, y el amante engañado el hijo apenas.

Óigame aquel que se llamare a engaño: los hombres hacen las mujeres buenas, y sólo por su culpa viene el daño ${ }^{\mathbf{3 1}}$.

A primera vista este soneto aparece algo caótico, y sólo cobra unidad encuadrado en un momento de reflexión en que experimenta el poeta un cambio en su sensibilidad erótica. Destaquemos el segundo cuarteto en el que triunfa una vez más su amor paternal cuando expresa tan llana y hondamente el placer que le inunda al coger en sus brazos desde la cuna al niño apenas despierto. Observemos que cuida de decirnos que es un hijo "en bendición", lo que nos prueba que se trata de Carlos Félix.

El resto del soneto está dedicado a ensalzar el matrimonio, el vínculo que hasta entonces había considerado un yugo insoportable "cárcel de la libertad y abreviatura de la vida" ${ }^{132}$. En La Jerusalén, que por rara casualidad salía a luz en aquellos días, había proclamado las excelencias del amor libre, del amor furtivo; ahora le parece necedad sujeta a engaño.

- Conoce el pajarillo el huevo extraño y el amante engañado el hijo apenas.

¿Le dió motivo Micaela para dudar que fuesen suyos todos los hijos cuya paternidad le atribuía en secreto, mientras que oficialmente eran inscritos con el apellido de Diego Díaz, el marido legítimo? Aquellos "dulces pajarillos" de que se apartaba con tanta pena al abandonar el nido sevillano, celoso de que otro pudiera disfrutarlo ies que no acertaba a discernir si eran suyos? Lo cierto es que tampoco de ellos volvemos a saber $^{133}$.

131 AcadN, vol. IV, pág. 338 a.

132 Epistolario, vol. III, pág. 5 .

${ }^{133}$ Cuando Lope enviudó, y acaso ya muerta Micaela, se llevó a vivir con él a los dos hijos últimamente nacidos: Marcela y Lope. 
Desaparecida Micaela, se opera en Lope un cambio de vida que no han tenido en cuenta sus biógrafos, más atentos a los escándalos que a los hechos virtuosos; es el momento de cordura en que vuelve los ojos a su hogar legítimo y busca la tranquilidad de conciencia. El soneto transcrito es una prueba de ello, y otra más clara, por estar exenta de todo artificio, nos la proporcionan las cartas al Duque de Sessa durante ese período. En ellas aparece con mucha frecuencia el nombre de doña Juana "de quien ya la vejez me ha hecho galán" dice en una carta; la pobre está siempre achacosa; a su lado pasa él insufribles noches, pero todo lo lleva con paciencia a que le obliga "su mucha virtud y bondad", y si tiene que acceder a algún capricho, nos dirá: "todo se lo sufro desde que me ha hecho padre". El hijo que había traído al mundo fué el encanto del padre y fuerte lazo que durante su corta vida retuvo al poeta sujeto a la vida familiar. También al Duque le cuenta una y otra vez las gracias de Carlitos. Todas esas intimidades prueban cuáles eran las preocupaciones familiares de Lope, que seguramente interesaría muy poco a su señor, más atento a las procacidades que para animarle en sus melancolías de perversión insatisfecha le escribía el complaciente secretario, dándole cínicos consejos en relación a los trapícheos del Duque con Floras, Jacintas y otras mujeres de toda laya.

Pero no hemos de seguir a Lope, que pronto vería deshecho su hogar por muerte de sus dos seres queridos, y cerramos el período Celia-Lucinda ${ }^{134}$.

Queda sentado que el deleite sensual de la posesión de Micaela se prolongó en Lope de los $3^{\mathrm{I}}$ años a los 46, lo más granado de su virilidad. No habrá quien le tache de inconstante: diez años le duró el regusto de Elena, quince la plenitud gozosa de Micaela, y luego dieciséis el ensimismamiento y la solicitud hacia doña Marta ${ }^{135}$.

El mal estuvo en que concurrieran paralelamente a estas pasiones siete años de cariñosa unión, nunca renunciada, con doña Isabel, quince atendiendo con más o menos constancia a la achacosa doña Juana y finalmente veintiún años de sacerdocio agitado por remordimientos, desmayos e ímpetus divinos. Y lo peor de todo para su fama es que lo contaba claramente, sin celar nada ${ }^{136}$.

${ }^{134}$ A ese período de asesamiento entre 16o9-1612, pertenece una densa producción literaria con manifestaciones de arrepentimiento y mayor intensidad religiosa: Los cuatro soliloquios (1610), Los Pastores de Belén, especie de Arcadia vuelta a lo divino; y en el teatro El caballero del Sacramento, La bella Ester, La buena guarda y Cardenal de Belén.

${ }_{135}$ Prescindo de otros amoríos de Lope, que serían muchos (tal catador era de deleites carnales), pero que no constituyeron verdadera pasión; así el amancebamiento con doña Antonia Trillo, el frenesí pasajero por Lucía de Salcedo y los ratos alegres que pasó con la generosa Jerónima de Burgos de la que nunca estuvo enamorado. Nada de esto trascendió a su obra literaria, y por lo tanto no nos interesa.

${ }^{136}$ Ya decía Quevedo: "Locos son estos hombres que se confiesan a voces". 
Sin embargo no hay por qué rasgarse las vestiduras, que no es Lope de Vega un caso insólito, pues en todos los tiempos hay hombres mal avenidos con la monogamia, y la sociedad ha perdonado (en el sexo fuerte, se entiende) los "yerros por amores" ${ }^{137}$. Como en una ocasión escribió Menéndez Pelayo: "a los poetas, seres leves y alados, no hay que pedirles tanta cuenta de sus asuntos como de sus versos". Así entreguémonos al placer de paladear la dulzura con que nos regala Lope al convertir en maravillosas poesías las apasionados momentos de su vida.

En cuanto al hombre, pensemos piadosamente que obtendría el perdón de sus pecados, pues no le faltó en muchas ocasiones sincero arrepentimiento, y en los últimos años se entregó a la penitencia, sufrió con resignación las penas que le conturbaron como expiación de sus culpas, y en muchas ocasiones ungió los pies del Redentor con el bálsamo precioso de sus versos sacros.

Chamartín de la Rosa.

María Goyri de Menéndez Pidal

${ }^{137}$ No es necesario aducir pruebas, que llenas están las historias de nombres de bastardos, hijos de católicos reyes, de ilustres príncipes de la Iglesia, de nobles y de varones de todas las clases sociales. 